\title{
Formation processes at a high resolution Middle Paleolithic site: Cueva Antón (Murcia, Spain)
}

\author{
Diego E. Angelucci ${ }^{a}$ * , Daniela Anesin ${ }^{a}$, Davide Susini ${ }^{a}$, Valentín Villaverde ${ }^{b}$, Josefina Zapata $^{c}$, \\ João Zilhão ${ }^{\mathrm{d}}$ \\ ${ }^{a}$ Dipartimento di Lettere e Filosofia, Università degli Studi di Trento, via T. Gar 14, 38122 Trento, Italy \\ ${ }^{\mathrm{b}}$ Departament de Prehistòria $i$ Arqueologia, Universitat de València, Spain \\ ${ }^{\mathrm{c}}$ Departamento de Zoología y Antropología Física, Facultad de Biología, Universidad de Murcia, Spain

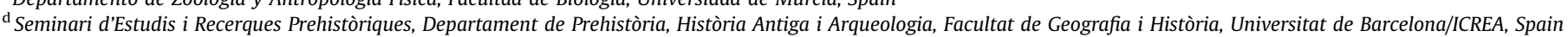

\section{A R T I C L E I N F O}

\section{Article history:}

Available online $\mathrm{xxx}$

\begin{abstract}
A B S T R A C T
Cueva Antón is a Middle Paleolithic rockshelter located in the valley of the River Mula (Murcia, Spain). The archeological investigation of the site, which began with salvage work in 1991, resumed in 2006 and is still ongoing, uncovered a succession spanning most of MIS 3 and MIS 4 (ca. 75-36 ka) and featuring a well preserved human occupation record. This paper presents the first information about site stratigraphy and site formation processes. Geoarcheological data collected in the field and through micromorphological observation show that the archeological succession at Cueva Antón is mainly composed of alluvial sediments, with thin intercalations of gravitational and slope material. The sedimentary characteristics of the alluvial succession are well preserved as the result of a rapid accumulation rate and the protective effect of the rockshelter. Several sedimentary facies produced by the shifting of distinct fluvial sub-environments (channel, bar and floodplain) are recognized. With the exception of a few units (II-u, a thin buried alluvial soil, and the archeologically richest units at the base of the succession), post-depositional modification is rare. The site was occupied within a framework of infrequent, short-term visits, resulting in a relatively low overall density of finds and the formation of well-defined archeological lenses that correspond to synchronous paleosurfaces preserving the spatial distribution of finds and features. This pattern explains the limited anthropogenic evidence observed in thin sections, even those from units where archeological excavation uncovered significant remains of human occupation.
\end{abstract}

(c) 2013 Elsevier Ltd and INQUA. All rights reserved.

\section{Introduction}

Cueva Antón is a Middle Paleolithic rockshelter located in the valley of River Mula (Figs. 1 and 2), in the Spanish region of Murcia (Martínez, 1997; Zilhão and Villaverde, 2008; Zilhão et al., 2010). The site was initially explored in 1991 but its full potential was only disclosed in the second phase of investigation, still in progress in 2012. Fieldwork at Cueva Antón has shown that its sedimentary fill is a high resolution succession that spans most of MIS 3 and MIS 4 (from ca. 75-55 to ca. 38-36 ka) and contains interstratified human occupation lenses. The data collected to date indicate that the succession preserved at Cueva Antón will shed critical light on the fate of the last Neanderthals of southern Europe and their

\footnotetext{
* Corresponding author.

E-mail address: diego.angelucci@lett.unitn.it (D.E. Angelucci).
}

behavioral patterns, as well as on the reconstruction of the climatic and environmental evolution of the region during the middle part of the Upper Pleistocene.

This paper focuses on site formation by taking into account the first geoarcheological data collected in the field and through the micromorphology of sediments and soils. The aim is to build a solid framework for understanding site stratigraphy and formation processes, a prerequisite for the construction of archeological and anthropological models concerning the last Neanderthals and the Middle-to-Upper Paleolithic transition (see Zilhão, 2006; Zilhão et al., 2010; Aubry et al., 2011; Mallol et al., 2012).

\section{Site presentation}

The salvage excavation carried out at Cueva Antón in 1991 exposed a 4-m-thick succession, at the base of which Middle Paleolithic occupations were identified (Martínez, 1997). Fieldwork 


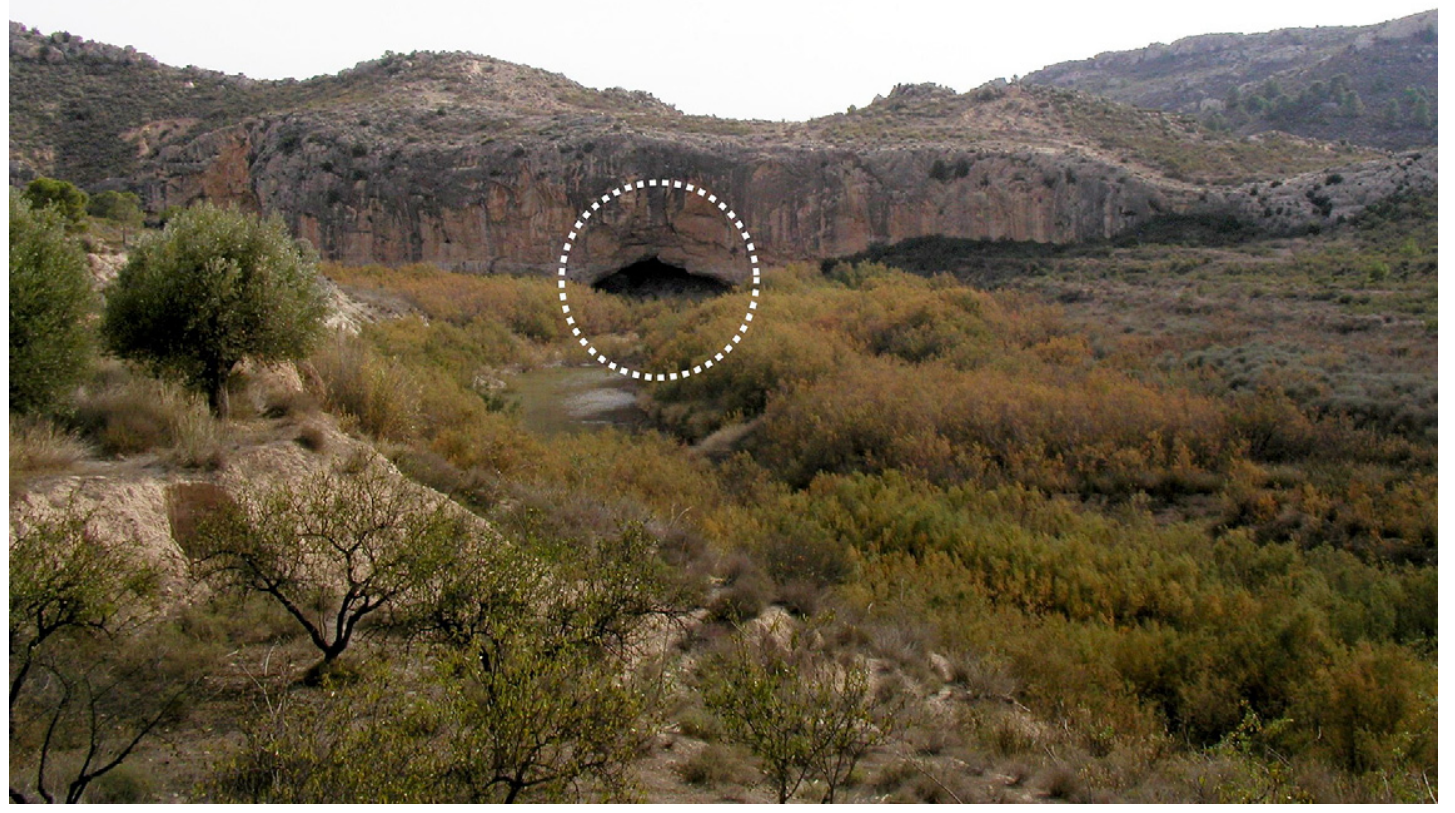

Fig. 1. The entrance of Cueva Antón (circle) seen from NW. The cave is located along a reverse-fault escarpment, in the valley of the River Mula (Murcia, Spain).
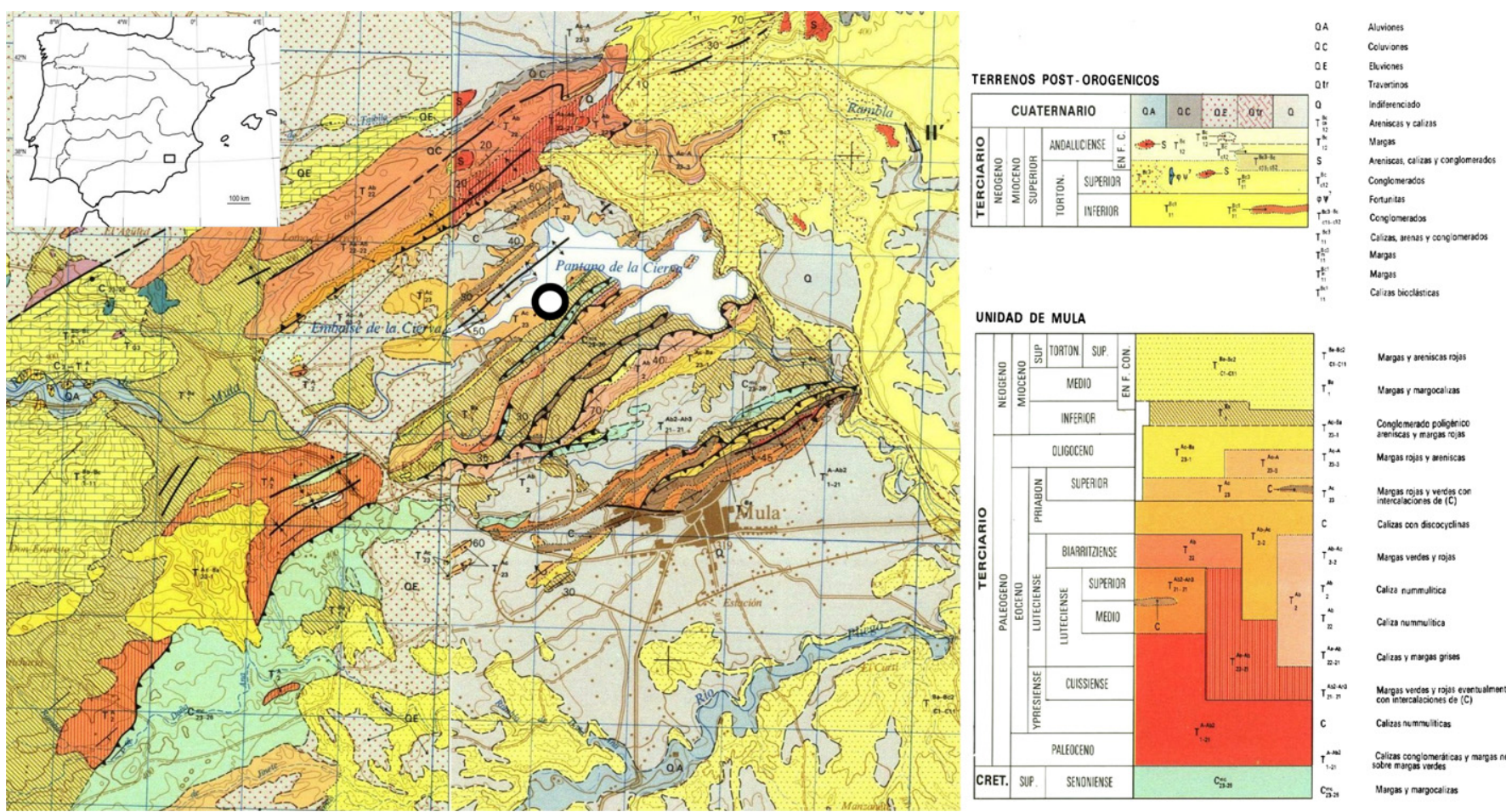

UNIDAD DE MULA

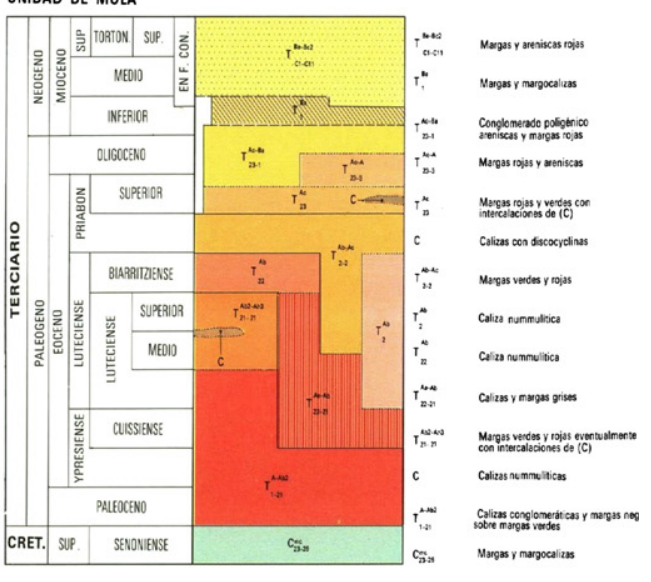

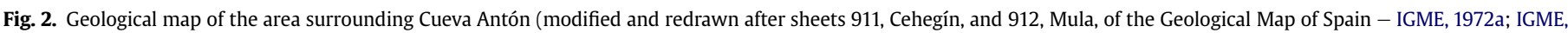
$1972 \mathrm{~b}$; see text for key - the black square in the map of Iberia corresponds to the area depicted in the geological map; site position is indicated by a circle). 
at the site resumed in 2006, when the old excavation sector (henceforth, "Trench I") was cleaned and sampled. Four additional field seasons have since been carried out (2007, 2008, 2011 and 2012), with the twin aims of exploring the site's archeological record through open-area excavation and sampling its stratification. A $1-\mathrm{m}^{2}$ sector (the so-called "telephone booth") was specifically excavated in 2011 in order to systematically characterize the archeological succession via flotation of all the sediments (in total, $\sim 2.5 \mathrm{~m}^{3}$ or 5 tonnes) for their charcoal, mollusk shell and microvertebrate components and the collection of samples for pollen and particle-size analysis.

Recent excavation work has shown that Middle Paleolithic occupations are present at different points in the deposit. The lowermost units are richer in finds and archeological features, but Cueva Antón was also occupied during the accumulation of the upper part of the succession. Where the lower units are concerned, Neanderthal occupants set camp at different points of the vast sheltered area (a surface measuring more than $600 \mathrm{~m}^{2}$ - Figs. 3 and 4) and over a time span during which the rockshelter was subject to almost continuous sediment accumulation (see below). Therefore, the record of human occupations is both horizontally and vertically clustered, and a large volume of the deposit has to be dug out in order to adequately assess site arrangement and stratigraphy.

Archeologically, the site produced abundant lithic assemblages of Mousterian affinities (Martínez, 1997; Zilhão et al., 2010). The most striking find from Cueva Antón is a perforated half-valve of the scallop Pecten maximus from layer I-k, which bears residues of pigment (a mix of goethite and hematite whose potential sources exist within approximately $5 \mathrm{~km}$ from the site) on its external surface (details in Zilhão et al., 2010). Archeological features, particularly hearths, were also detected in the lowermost units during the 2011 and 2012 field seasons (for this reason, they are not dealt with in this paper).

Faunal remains are common at the site, and microvertebrate ones abundant (Sanchis, 2012), as is charcoal, whose ongoing analysis provides clues to the environmental evolution of south-eastern Iberia during MIS 3 and MIS 4 (Badal et al., 2012). A detailed reconstruction of the climatic and environmental significance of the deposit must await a refined chronometric background. However, the first data on wood charcoal remains indicate that the deposit was formed with average temperatures colder than present and predominantly under xeric conditions, suggesting that the south-east was already one of the driest parts of Iberia at this time (Badal et al., 2012). However, some deciduous trees, including Salix/Populus, are present from top to bottom, indicating the existence of a riparian woodland (Badal et al., 2012), as also suggested by the presence of Castor fiber remains among the natural background fauna (layer II- $t$ ).

Radiocarbon dating results are available for the upper part of the succession. One result obtained on a Pinus nigra-type sample from excavation unit "I-k/II-d" pre-treated with the ABOx-SC (Acid-BaseOxidation-Stepped Combustion) methodology, returned a date of $32,890 \pm 200$ bp (OxA- 21244). The "I-k/II-d" excavation unit corresponds to the whole, undifferentiated package of strata I-k, II-a, II-c, II-b and II-d in squares J19, K19 and J18 (see Fig. 7), excavated in 2008 from an area of the site where each of those levels thinned to the extent that their distinction, although visible in profile view, was not recognizable in plan view. The field notes, however, specify that the dated charcoal was contained in a "large silt prism", which implies assignment to layer II-b (not to layer I-k, as previously published; Zilhão et al., 2010). However, as the contextual evidence indicates that this sediment package accumulated very rapidly and over an interval of time of the order of magnitude of (or even shorter than) the error associated with radiocarbon dates in this time range, the correction, offered here for the sake of accuracy, has no impact on the archeological and stratigraphic significance of these deposits and their contents. The calibration of this date with the high resolution records available for this period (Fairbanks, 2005; Hughen et al., 2006; see also Zilhão et al., 2010) within a Bayesian framework (Bronk Ramsey, 2009) places the human occupation ca. 38-36.5 ka, towards the end of GIS 8. Preliminary OSL dating of the mid-lower part of the sequence (on samples from units II-e, II-y, III-f and III-m) yielded ages in the ca. 55-75 ka range (Zilhão et al., 2012), indicating that a significant hiatus could exist between the upper (sub-complex AS1, see below) and mid-lower parts of the alluvial succession.

\section{Regional setting}

Cueva Antón is located in the Mula valley at an altitude of $355.97 \mathrm{~m}$ asl (elevation of the site datum; Figs. 1-3). The site is set at the upstream entrance to the El Corcovado gorge, nowadays at the tail end of an artificial reservoir, the Embalse de La Cierva, facing the outer side of a meander of the River Mula. The rockshelter is excavated into the base of a fault escarpment modeled into Eocene

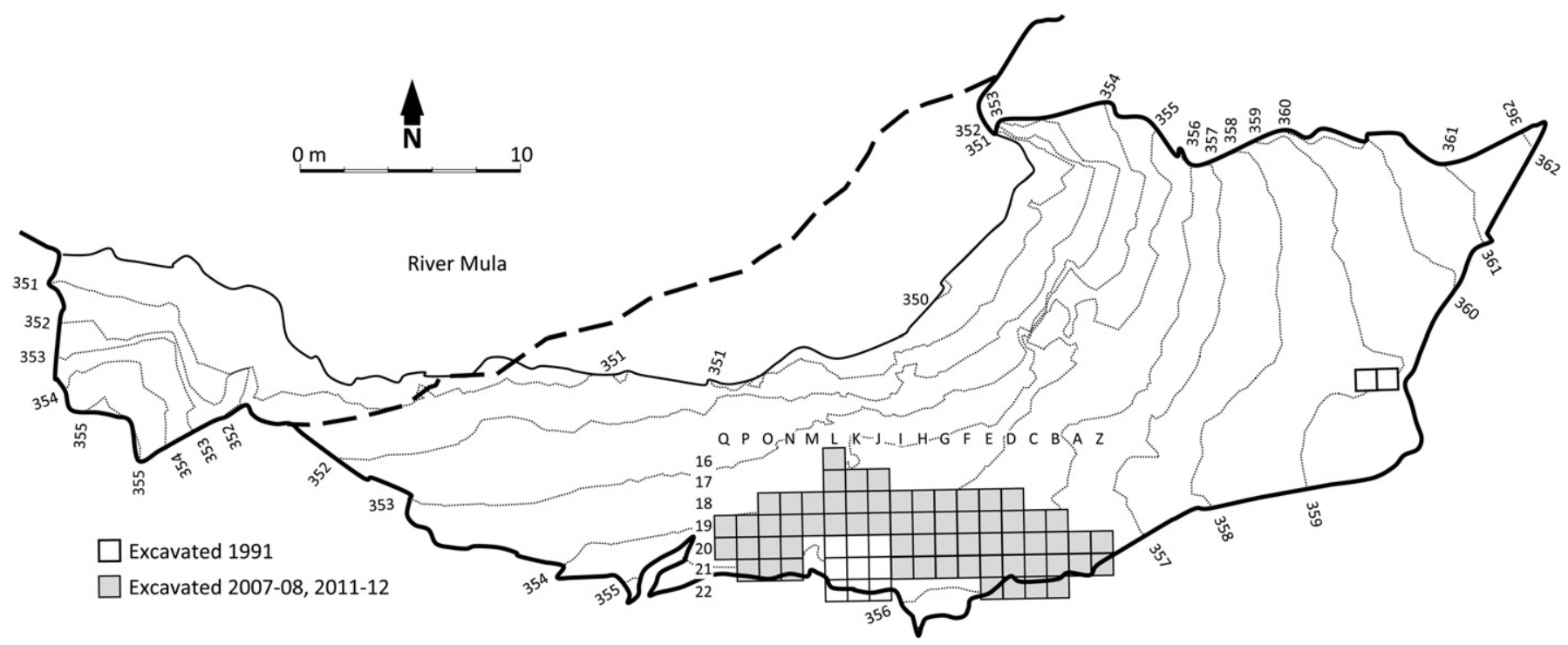

Fig. 3. Cueva Antón. Site plan and excavated areas (elevation in meters asl). 


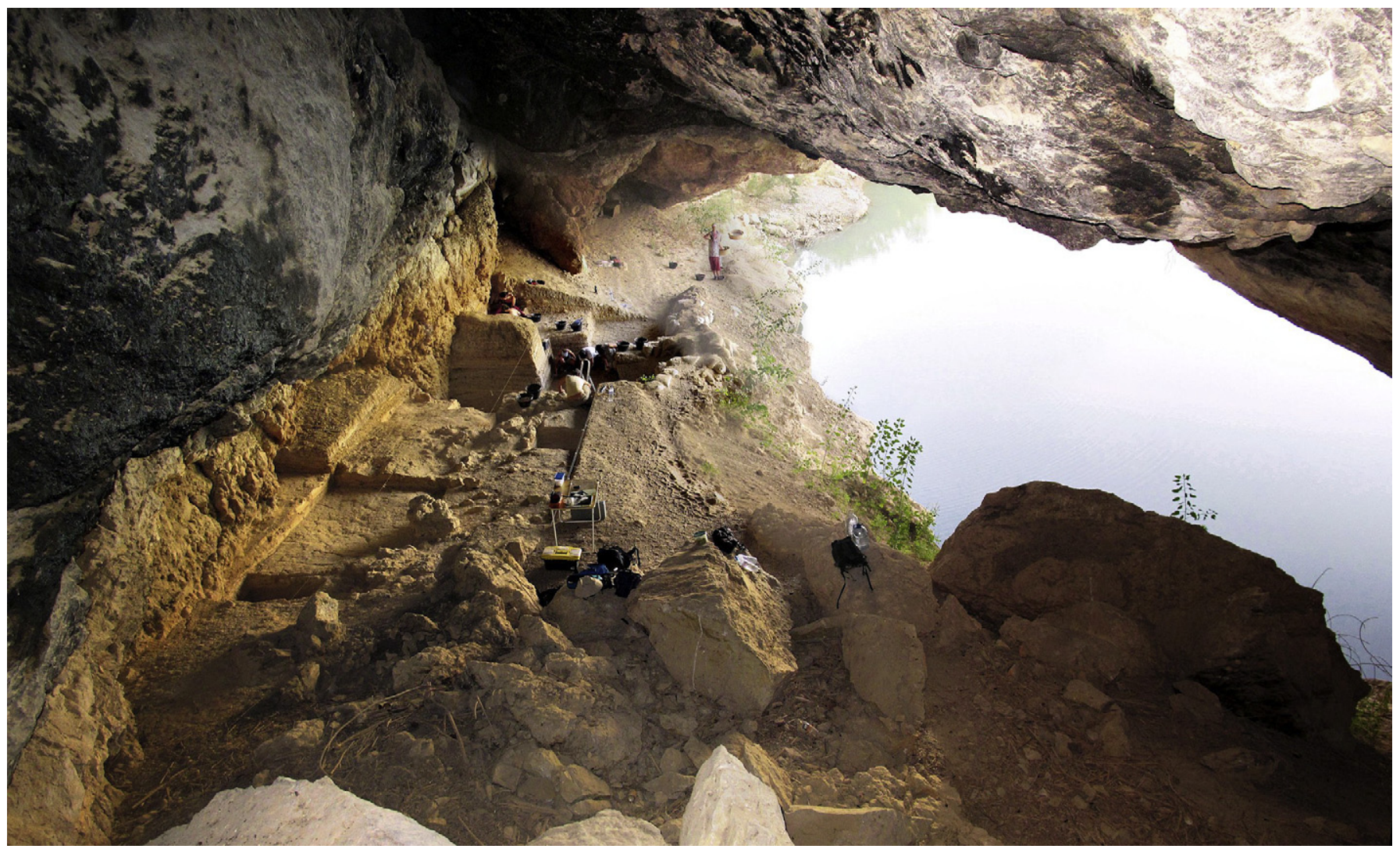

Fig. 4. Interior view of Cueva Antón from E, during the 2012 field season.

limestone along the right bank of the river. The site's bedrock includes distinct types of limestone: calcareous breccia and conglomerate, calcarenite, and micritic and nummulitic limestone.

The River Mula, whose drainage basin spreads over a surface of $\sim 660 \mathrm{~km}^{2}$, is a right tributary of the River Segura. Water discharge of the Mula is highly variable due to the regional climatic situation:

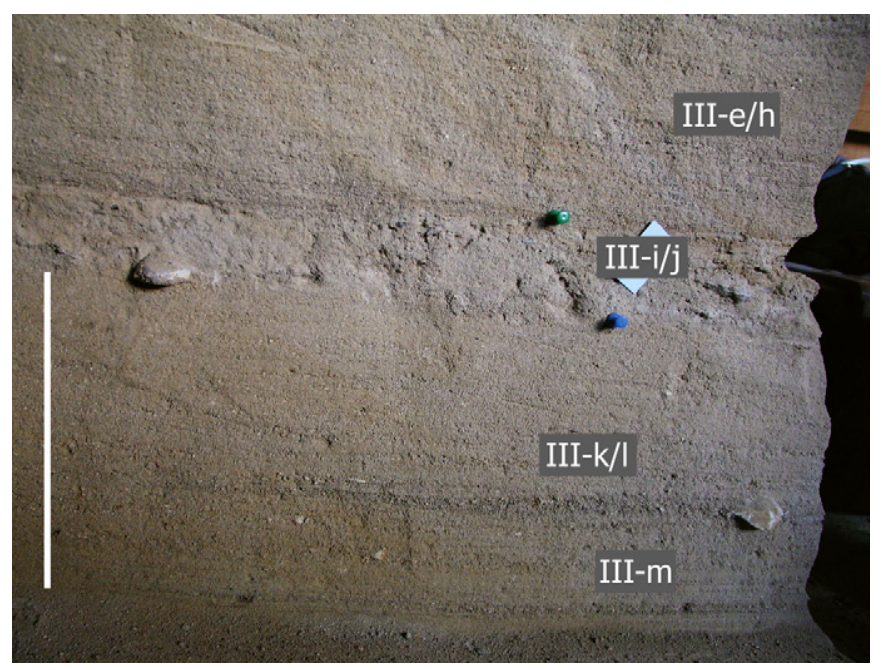

Fig. 5. Cueva Antón. The archeological succession at the base of sub-complex AS5 in the W wall of square L20, showing the alternation between sand facies clearly differentiated for their grain size and the presence of sedimentary features (scale bar is $20 \mathrm{~cm}$; labels correspond to the excavation units, which sometimes combine different geoarcheological units as a result of lateral thinning or heteropy; see Fig. 7 for the location of this picture in the section). at the Embalse de La Cierva dam, mean annual temperature is $19.7{ }^{\circ} \mathrm{C}$, mean annual rainfall is $\sim 300 \mathrm{~mm}$ and potential evapotranspiration is approximately $900 \mathrm{~mm} / \mathrm{y}$, which means a rather negative water balance of $\sim 600 \mathrm{~mm} / \mathrm{y}$. Rainfall is unevenly distributed throughout the year, with relative positive peaks during spring and fall, and values ranging between 60 and $645 \mathrm{~mm} / \mathrm{y}$ from year to year (Gómez Espín et al., 2005). The present climate is responsible for dominant thermic soil temperature regimes and aridic (xeric at some places) soil moisture regimes. The main soil type in the area, according to Soil Taxonomy (Soil Survey Staff, 1999), is Calciorthid, dominated by the accumulation of calcium carbonate in the profile, but Torrifluvent and Torriorthent, poorly developed soils, formed under an aridic moisture regime, are also found (García Cortés et al., 1999).

The Mula valley lies in a tectonic depression of the eastern Betic cordillera, an ENE-WSW trending mountain belt that formed during the Alpine orogeny and has been tectonically active throughout the late Cenozoic (Giménez et al., 2000; Masana et al., 2005). The Betic chain exhibits quite complex geological and structural setting, and significant structural and tectonic control on surface morphologies and sediment. Rock formations of the Mula valley mostly formed inside the Mula-Pliego piggy-back basin since the late Mesozoic (Martín-Martín and Martín-Algarra, 2002). Two main groups of formations outcrop in the surroundings of Cueva Antón (Fig. 2):

- Cretaceous to upper Miocene sedimentary rocks, mostly limestone and marl, with occasional sandstone and conglomerate, intensely affected by Alpine tectonic movements, and belonging to the paleogeographic and structural domain called "Mula tectonic unit", which forms a rather tight NW-SE oriented anticline, partly covered by post-orogene sediments ("UNIDAD DE MULA" in Fig. 2). Both flanks of the anticline exhibit 

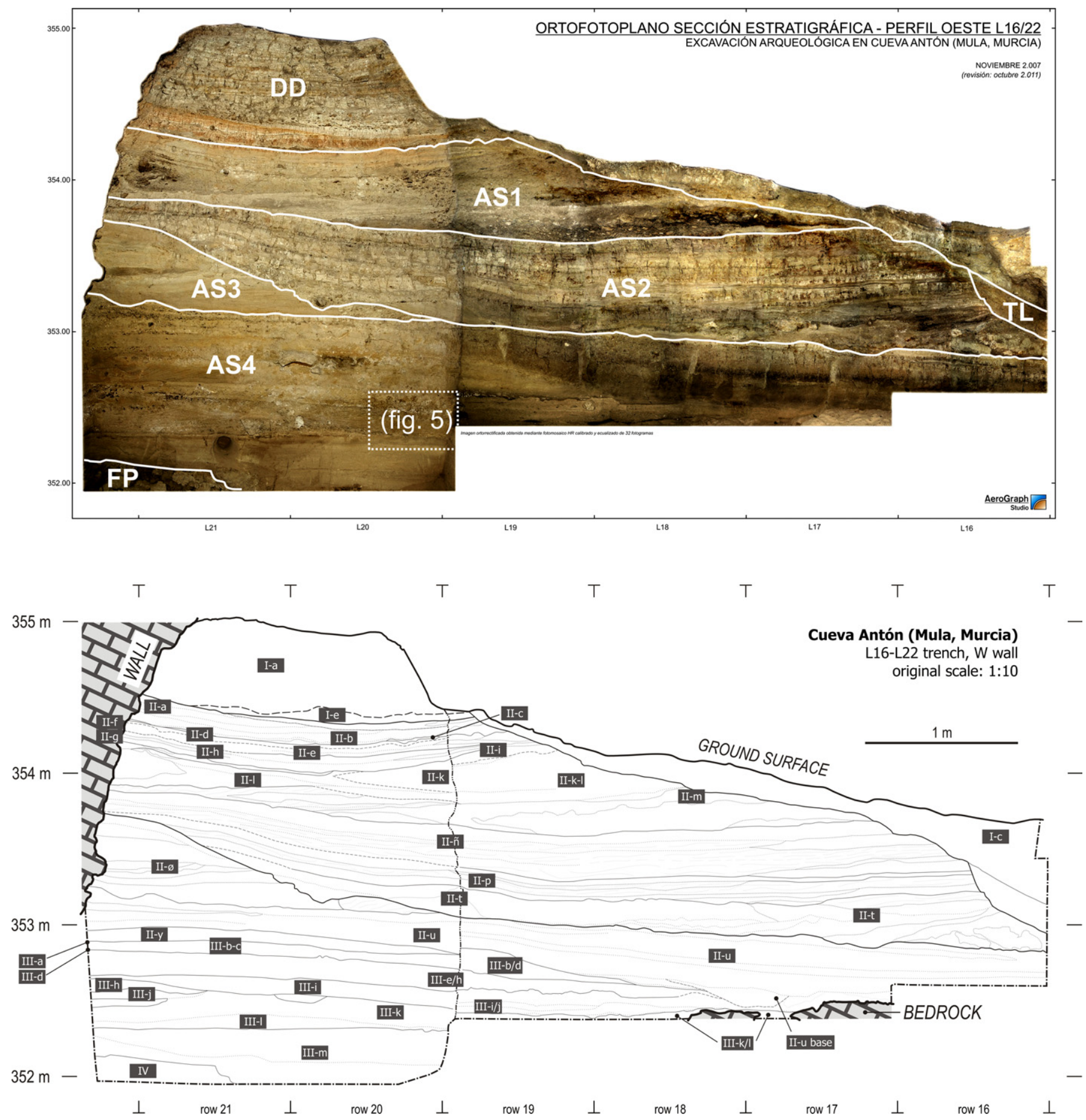

Fig. 6. Cueva Antón. Cross-section along squares L16 to L22, W wall of the excavation at the end of the 2011 field season. Top: orthorectified photomosaic restitution (by AeroGraph studio), with indication of stratigraphic complexes and sub-complexes; the dotted square corresponds to the position of the picture in Fig. 5. Bottom: drawing, with indication of excavation units (elevation in meters asl).

overthrusts directed towards the fold axis: the Cueva Antón escarpment corresponds to the front of one of these overthrusts.

- Post-orogene materials ("TERRENOS POST-OROGÉNICOS" in Fig. 2), comprising Upper Miocene sedimentary (marl, conglomerate, limestone) and volcanic rocks, as well as Quaternary sediments, mainly related to slope and alluvial dynamics (IGME, 1972a; IGME, 1972b).

The alluvial deposits that outcrop in the valley were mostly produced by the activity of the River Mula, whose basin opened in the early Quaternary (Mather et al., 1995). Alluvial terraces are well developed along the valley slopes. Mather et al. (1995) identified six main systems of Mula alluvial terraces, at relative heights of $65 \mathrm{~m}, 40 \mathrm{~m}, 32-36 \mathrm{~m}, 15 \mathrm{~m}, 5 \mathrm{~m}$ and $2 \mathrm{~m}$. A preliminary geomorphological survey undertaken in the context of the Cueva Antón project has allowed identification of another terrace ca. 20-22 m above the present riverbed, and shown that the $+5-7 \mathrm{~m}$ terrace is well developed in the reach of the valley around Cueva Antón and often consists of gravels up to ca. 3 m-thick. All the terraces (with the exception of that at 32-36 m) show fluvial characteristics and 


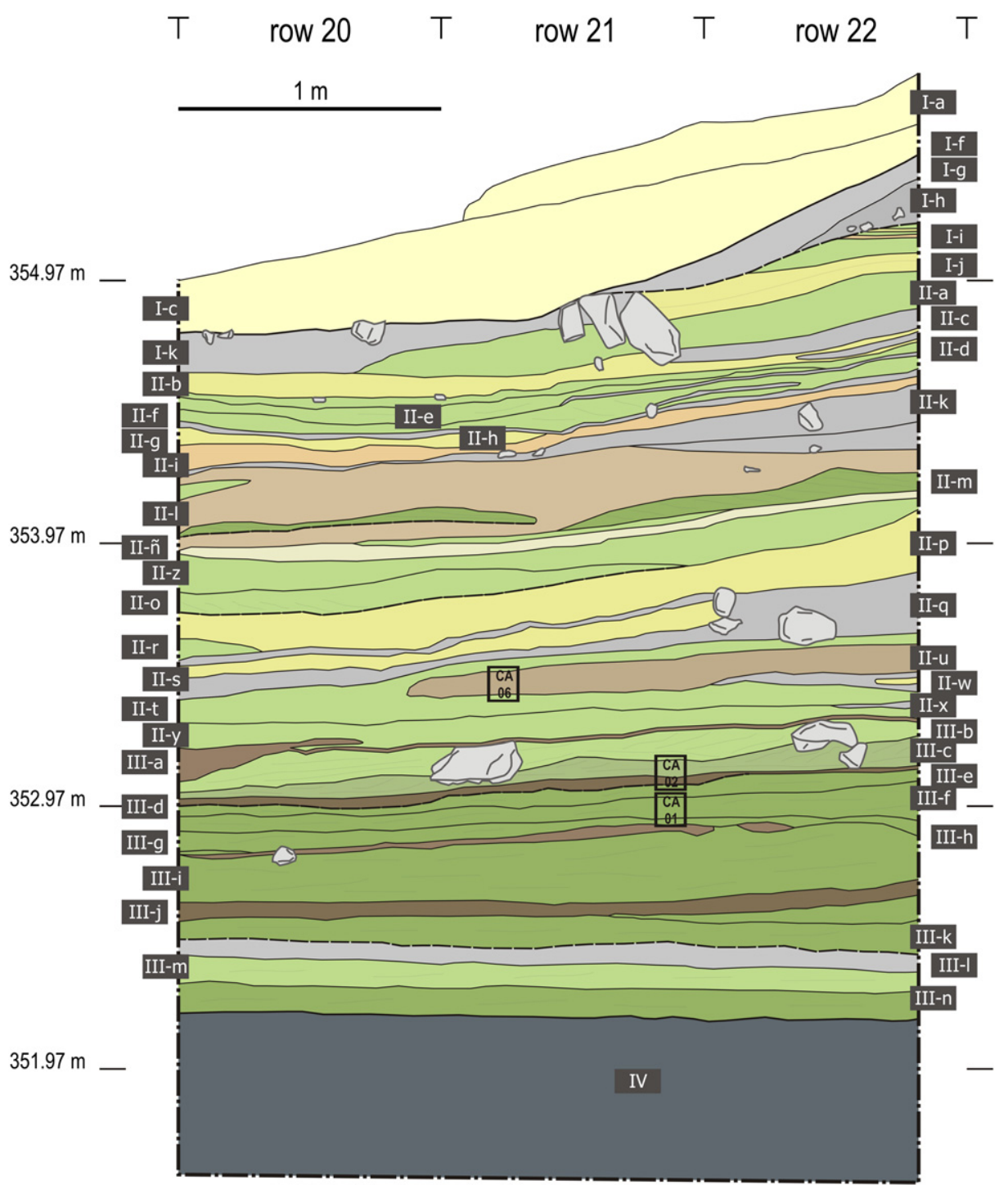

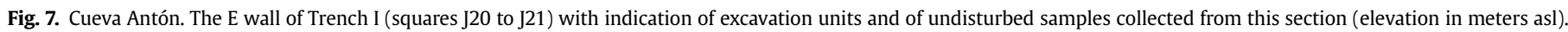

their bulk is formed of 'classical' fluvial sedimentary facies (see Mather et al., 1995).

On close inspection, Cueva Antón is shaped as a large cavern entrance whose arched roof stands a few meters above the present riverbed and whose access is marked by a rock threshold (Figs. 1 and 4). The rockshelter roof and walls are built of solid limestone but for an $\mathrm{E}-\mathrm{W}$ subvertical crack that runs along the entire length of the roof. The origin of the rockshelter is the result of a number of processes, namely karst dynamics, differential erosion (acting, in particular, on the rock of the structurally weakened zone), lateral erosion by the River Mula, and wall degradation.

\section{Materials and methods}

During the second phase of fieldwork at Cueva Antón, geoarcheologists participated in all phases of excavation in order to guarantee accurate feedback between archeological questions and earth science methods. Initially, in 2006, extant exposures of the 1991 excavation were cleaned, redrawn, described and sampled. During the following seasons all excavated layers were described, while sections were drawn by traditional techniques or recorded through orthorectified photographic restitution. Sediment descriptions took into account sedimentary, pedogenetic, stratigraphic and archeological features. The naming of archeological units follows the original designation given in 1991, with additions for the new units recognized since.

The Cueva Antón succession is mostly made up of sediments with recurrent features. The archeological deposits (stratigraphic complex AS, see below), in particular, include several superposed and juxtaposed layers whose repetitive composition, textural characteristics and sedimentary features, are amenable to grouping under a small set of sediment types (see Fig. 5). For this reason, the operational tool used in the description and sampling of the succession was the sedimentary facies (lithofacies), that is, the combination of physical characteristics displayed by a single layer or by a set of layers (e.g. Moore, 1949; Ricci Lucchi, 1980; for discussions of the use of the facies concept in archeology see Macphail et al., 1997; Courty, 2001; and also Angelucci et al., 2009; Angelucci and Anesin, 2012). A specifically designed list of facies (Table 1) was created and cross-checked over the years; at the same time, the facies type was systematically recorded during excavation and sampling, and reported in site records. Naming of the facies used an alphabetical code: the first letter, in upper case, indicates the lithology of the sediment (see Table 1 for details), while additional letters, in lower case, refer to other characteristics such as support, grain size, color, or sedimentary features. Most of the succession's 
units show characteristics that easily fit within one of the defined lithofacies. Some, however, match none and were described individually, with all their characteristics (e.g. unit II-u).
Thin sections were observed under a polarizing microscope at magnifications between $25 \times$ and $1000 \times$, using plane-polarized light (PPL), crossed-polarized light (XPL) and incident light, the

Table 1

List of sedimentary facies defined at Cueva Antón and related units. Key: (pp) - partly.

\begin{tabular}{|c|c|c|}
\hline Name & Description & Units \\
\hline Bcf & $\begin{array}{l}\text { Breccia formed of angular fragments of limestone, on average 1-cm large, platy, with discrete sorting } \\
\text { of sedimentary skeleton, often with subhorizontal orientation pattern (locally convoluted); clast- } \\
\text { supported; matrix is clayey silt, 7.5YR } 5 / 4 \text { (moist), firm, with low porosity and no organic matter; } \\
\text { slightly cemented by calcium carbonate, with massive carbonation and carbonate capping on some } \\
\text { stones. Forms lenticular-shaped or cuneiform layers, horizontal or weakly dipping N (outwards), } \\
\text { with maximum thickness near back wall }\end{array}$ & I-g, I-k, II-c, II-g, II-k (pp), II-w, III-l (pp) \\
\hline $\mathrm{Bcm}$ & $\begin{array}{l}\text { Breccia formed of angular and subangular fragments of limestone, with two main types of clasts: (a) } \\
\text { platy, angular, on average } 1-\mathrm{cm} \text { large, with subhorizontal orientation pattern; (b) } 1-5 \mathrm{~cm} \text { large, } \\
\text { subangular and subrounded; matrix is clayey silt, } 7.5 Y R \text { R } 5 \text { (moist), firm, with low porosity and no } \\
\text { organic matter; slightly cemented by calcium carbonate, with massive carbonation and carbonate } \\
\text { capping on some stones. Shows the same geometric characteristics as Bcf strata }\end{array}$ & I-h, II-q \\
\hline $\mathrm{GR} / \mathrm{G}$ & $\begin{array}{l}\text { Fine gravel (GR) or gravel (G), clast-supported, polygenetic, formed of rounded to well-rounded } \\
\text { elements. Forms lenticular layers dipping NW, usually with abrupt erosive lower boundary }\end{array}$ & II-k (pp), II-m (pp), II-t (pp), \\
\hline Lmb/Lmy & $\begin{array}{l}\text { Silt, without stones; massive, firm, with low porosity and no organic matter; moderately cemented } \\
\text { by calcium carbonate; } 1 Y 4 / 3(\mathrm{Lmb}) \text { or } 2.5 \mathrm{Y} 7 / 2 \text { (Lmy). Layers are mostly tabular }\end{array}$ & $\begin{array}{l}\text { I-i (pp), II-b, II-h, II-i, II-l (pp), II-ñ (pp), } \\
\text { II-p, II-s, II-ø (pp), }\end{array}$ \\
\hline Mby & $\begin{array}{l}\text { Marl (clayey silt), without stones; } 10 \mathrm{YR} 7 / 4 \text { (moist); weakly recognizable parallel flat lamination, } \\
\text { well-developed boudinage and thin, continuous manganese-oxide coatings. Layers are mostly } \\
\text { tabular }\end{array}$ & $\mathrm{I}-\mathrm{j}$ \\
\hline Mmy & $\begin{array}{l}\text { Marl (clayey silt), without stones; } 2.5 Y 7 / 3 \text { (dry) and } 10 \text { YR } 7 / 4 \text { (moist); weakly recognizable parallel } \\
\text { flat lamination; post-depositional cracking and thin, continuous manganese-oxide coatings. Layers } \\
\text { are mostly tabular }\end{array}$ & II-ñ (pp) \\
\hline $\mathrm{Sfl} / \mathrm{Sfm}$ & $\begin{array}{l}\text { Very fine sand, slightly silty, without stones; 9YR 6/4; well-sorted and discretely packed; dense } \\
\text { parallel flat and low-angle lamination (Sfl) or massive (Sfm); moderately cemented by calcium } \\
\text { carbonate. Forms lenticular layers, mostly dipping NW }\end{array}$ & $\begin{array}{l}\text { I-i (pp), II-a, II-d, II-e, II-f, II-k (pp), II-l (pp), } \\
\text { II-ñ (pp), II-z, II-o, II-t (pp), II-ø (pp), II-y, III-b, } \\
\text { III-c, III-l (pp), III-m }\end{array}$ \\
\hline $\mathrm{Sml} / \mathrm{Sgl}$ & $\begin{array}{l}\text { Sand, fine to medium (Sml) or coarse (Sgl), with cross stratification; } 10 \text { YR } 5 / 4 \text { (moist); well sorted } \\
\text { and discretely packed; moderately cemented by calcium carbonate. Forms lenticular layers dipping } \\
\text { NW, usually with abrupt erosive lower boundary }\end{array}$ & $\begin{array}{l}\text { II-m (pp), II-t (pp), II-ø (pp), III-e, III-f, III-g, } \\
\text { III-I, III-k, III-n }\end{array}$ \\
\hline K & Carbonate crust & \\
\hline
\end{tabular}

Fourteen samples collected during fieldwork for micromorphological analysis have already been analyzed (Table 2). Undisturbed samples could be simply cut out, because of the good cohesion of the sediment; wrapped in paper and marked, they were then oven-dried at $60^{\circ} \mathrm{C}$ until a constant weight was attained. Thin sections were prepared at the "Servizi per la Geologia" laboratory (Piombino, Italy), in the following stages: impregnation with a mixture of resin, styrene and hardener; curing; cutting into cmthick slabs; and final preparation of $25-\mu$ m-thick sections, measuring $95 \mathrm{~mm}$ by $55 \mathrm{~mm}$.

Table 2

Cueva Antón: list of thin sections. Key: sq. - square; facies - see Table 1. For the location of excavation sectors see Fig. 2.

\begin{tabular}{|c|c|c|c|c|}
\hline Label & Year & Provenance & Layer(s) & Description/ facies \\
\hline CA-01 & 2006 & Trench I, section E & $\begin{array}{l}\text { III-e, III-f, } \\
\text { III-g }\end{array}$ & Sml \\
\hline CA-02 & 2006 & Trench I, section E & III-c, III-d & Sml + archeological layer \\
\hline CA-03 & 2006 & Trench I, section E & $\begin{array}{l}\text { III-g, III-h, } \\
\text { III-i }\end{array}$ & From top: Sml, K, Sml/Sfl \\
\hline CA-04 & 2006 & Trench I, sq. L20 & IV & \\
\hline CA-05 & 2006 & Trench I, section W & II-ñ & Lmy \\
\hline CA-06 & 2006 & Trench I, section E & II-u & \\
\hline CA-07 & 2008 & $\begin{array}{l}\text { Excavation surface, } \\
\text { sq. K18 }\end{array}$ & II-u & Mid part of II-u \\
\hline CA-08 & 2008 & $\begin{array}{l}\text { Sector I, section W, } \\
\text { sq. L20 }\end{array}$ & II-p & Lly \\
\hline CA1101 & 2011 & Section W, sq. L18 & III-i, III-j & \\
\hline CA1102 & 2011 & Section W, sq. L17 & II-u & $\begin{array}{l}\text { Base of II-u \& } \\
\text { underlying units }\end{array}$ \\
\hline CA1103 & 2011 & $\begin{array}{l}\text { "Telephone booth", } \\
\text { sq. I20-E }\end{array}$ & II-u & Top of II-u \\
\hline CA1104 & 2011 & Square N21-W & II-b & Lmb \\
\hline CA1105 & 2011 & $\begin{array}{l}\text { "Telephone booth", } \\
\text { sq. I20-E }\end{array}$ & II-l & \\
\hline CA1106 & 2011 & Section S & II-k & Bcf, cemented \\
\hline
\end{tabular}

latter for observation in standard light conditions and for primary fluorescence. Fluorescence observation was performed using two distinct wideband filter combinations: ultraviolet and blue (super wideband), with excitation filters respectively between 330-335 and $420-480 \mathrm{~nm}$, and corresponding suppression filters at 420 and $520 \mathrm{~nm}$. Images were captured through a digital camera for polarizing microscopy. Thin section description follows the guidelines proposed by Bullock et al. (1985) and Stoops (2003).

\section{Stratigraphy}

\subsection{Stratigraphic layout}

The succession filling Cueva Antón can be divided into four main complexes (Figs. 6 and 7) on the basis of stratigraphic criteria. These complexes are, from top to bottom:

- DD (Dam Deposit, which corresponds to units I-a to I-f): fine, mostly silty beds accumulated over the last decades by the transgression of the La Cierva reservoir inside the rockshelter;

- TL (Transitional Layers): disturbed layers of uncertain age overlying the Pleistocene sediments and abutting the dam deposits (backdirt from the 1991 trench, at least in part);

- AS (Archeological Succession; corresponding to units I-g to III$\mathrm{m})$ : Upper Pleistocene superposed alluvial sequences made up of distinct sedimentary facies, showing clear lateral variations and including intercalations of gravitational and slope material, particularly near the back wall;

- FP (Fine Paludal; corresponding to unit IV): a fine organic sediment, weakly bedded, with common vegetation pseudomorphs, a few charcoal fragments and rare terrestrial snail shells, lying at the bottom of the exposed succession. 


\subsection{Description of the archeological succession}

The succession of archeological interest (complex AS) corresponds to a well-preserved alluvial sequence whose characteristics were maintained thanks to the high rate of sedimentation and to the protection of the rockshelter, which reduced the impact of postdepositional modifications and soil formation processes on the deposit (details below). The succession is made up of superimposed alluvial sequences that may include thin buried alluvial soils, shows significant lateral facies variations due to modifications of the sedimentary dynamics during deposition, and contains inputs from the cave wall (limestone fragments of varied size and shape, see below), particularly in its uppermost part and towards the back. Carbonate accumulation, leading to cementation (moderate to intense), affects many of the units.

Taking into account sedimentary and stratigraphic criteria and the presence of erosive surfaces, complex AS has been subdivided into five sub-complexes (see Table 3 for details). lamination; II-i, Lmb; II-k, Bcf, with some large (up to $10 \mathrm{~cm}$ ) limestone fragments in the $\mathrm{E}$ side of the site, more complex northwards, where it is made up, from top, of Bcf, Sfl, and a structureless clastic bar with $\mathrm{mm}$ - to $\mathrm{cm}$-sized limestone fragments and occasional rounded fine gravel in a silty sand matrix.

The lower cycle begins with II-l. In the E part of the site, this unit is a composite set of Lm layers, with coarser inputs close to the wall and an abrupt, erosive lower boundary and can be subdivided into "II-l up" (matrix supported breccia) and "II-l low" (Lmb and Lmy facies, with scarce limestone fragments from the wall), separated by a discontinuous carbonate crust. To the $\mathrm{W}$, the unit is thicker and more complex, and includes, from top, a thin layer of Sfl and three juxtaposed lenses of $\mathrm{Sgl}$ with (1) some fine gravel and $\mathrm{cm}$-sized fragments of reworked sediment, (2) common limestone fragments, including slabs, and (3) some small sub-rounded pebbles. The underlying II- $\mathrm{m}$ is, to the $\mathrm{E}, \mathrm{Sml}$ in discontinuous lenses, passing to well rounded fine gravel $(0.5-3 \mathrm{~cm})$ in a sand matrix, coarser and more articulated to the $\mathrm{N}$; here, from top, it consists of fine gravel

Table 3

Cueva Antón. The five alluvial sequences in complex AS.

\begin{tabular}{|c|c|c|c|}
\hline \# & Short description & Base & Corresponding excavation units \\
\hline AS1 & Upper part, with slope/wall inputs and fine alluvial & Paraconformity & I-g (and unnamed upper units) to II-b \\
\hline AS2 & Mainly alluvial sediment, forming at least three minor cycles & Erosive disconformity & II-d to II-m (partly) \\
\hline AS3 & Mainly alluvial sediment, forming at least three minor cycles & Erosive disconformity & II-ñ to II-t \\
\hline AS4 & Sand layers observed in L21-L22 & Paraconformity & II- $\varnothing$ \\
\hline AS5 & $\begin{array}{l}\text { Mainly alluvial sediment with a poorly developed buried soil } \\
\text { on top, forming at least four minor cycles }\end{array}$ & Paraconformity & II-u to III-n \\
\hline
\end{tabular}

\subsubsection{Sub-complex AS1}

The uppermost sequence of the archeological succession, subcomplex AS1, is rather thin (ca. $40 \mathrm{~cm}$ ). Inputs from the wall are common. Due to the geometry of the erosive surface dividing it from the lower levels of the Archeological Succession, sub-complex AS1 is preserved only towards the back wall. Its base is a paraconcordant unconformity which rests on top of the underlying subcomplex AS2 (Fig. 6).

Sub-complex AS1 includes two sequences. The upper one is composed, from top to bottom, of deposits of the Bcf, Lmy/b, Bcf, and Lmb facies (for the list of facies see Table 1) that are present against the back wall only and lack an archeological denomination because they have not been excavated. The lower sequence includes the following layers: I-g, Bcf, partially open-work, with abrupt, erosive lower boundary; I-h, Bcm, with abrupt, erosive lower boundary; I-i, three superimposed facies (from top, Lmy, Lmb, Sfl) forming a positive alluvial cycle; I-k, Bcf, with coarser inputs, is the most recent archeological layer, has been already excavated over an area of $47 \mathrm{~m}^{2}$ and yielded a poor but diagnostic Middle Paleolithic artifact assemblage, including a perforated and painted Pecten maximus shell (Zilhão et al., 2010 - see Fig. 7); I-j, Mby; II-a, Sfm; II-c, Bcf with thin intercalations of Lmb; II-b, Lmy, with occasional angular limestone fragments around $1 \mathrm{~cm}$-long and some very fine sand.

\subsubsection{Sub-complex AS2}

Sub-complex AS2 is mainly composed of fluvial sediments that form at least three minor alluvial cycles. The base of this subcomplex is an erosive disconformity (Fig. 6).

The upper cycle is articulated as follows: II-d, Sfm; II-e, Sfl; a thin discontinuous layer of Bcf, with no archeological designation, between II-e and II-f; II-f, Sfl, with thin discontinuous intercalations of Bcf and an abrupt lower boundary.

The intermediate sequence includes the following units: II-g, Bcf, becoming discontinuous northwards; II-h, alternations of Lmy and Lmb, with some fine sand fraction and parallel flat (mostly composed of carbonate lithologies, with occasional small quartz granules), gravel (formed of rounded and well-rounded clasts, with a sandy matrix), and a basal Sml-Sgl lens (Fig. 6).

\subsubsection{Sub-complex AS3}

Sub-complex AS3 mainly consists of fluvial sediment, which is articulated into three alluvial cycles. Its lower boundary changes from the north, where it is an erosive disconformity, to the south, where it is a paraconformity adapting to the pre-existing geometry of underlying unit II-u (Fig. 6).

The upper sequence of the sub-complex includes the following units: II-n, K; II-ñ, Mmy, with a thin brunified (7.5YR 5/4) horizon on top, thickening to the north, where it forms a concave-concaveshaped sequence fining southward following the sequence Lmy, Lly passing laterally (southward) to a Sml lenticular layer, Lly, Sfl, Lly, and Sml; II-z, Sfm; II-o, Sfl, with abrupt erosive base and a carbonate crust on top.

The intermediate cycle corresponds to unit II-p, which, to the south, is Lmb with some sand, thickening to the north to form a concave-shaped sequence with grain size fining southward following the sequence Mmy, Sml passing laterally to Sfl and Lly, Lly, Lmy.

The lower sequence of sub-complex AS3 is articulated as follows: II-q, Bcm, with an intercalation of Lmb; II-s, Lmb, with some sand; II-t, which, to the south, is Sfm and, to the north, thickens significantly and gets more complex, including several subunits dipping south (towards the wall) following the sequence (1) structureless gray fine sand, hard, chaotic, with scarce small limestone fragments, (2) rounded gravel, with erosive lower boundary and a concentration of angular limestone fragments at the base, (3) thin lenticular layer of rounded fine gravel, (4) lenticular layer of Sfl passing to Sml, (5) 30-cm thick gravel layer, clast-supported, with cross-stratification (sequence, from top: Sgm/GRfm, $2 \mathrm{~cm}$ thick; GRm, $4 \mathrm{~cm}$; Sgm/GRfm, $2 \mathrm{~cm}$, passes laterally to Sfm intercalations; $\mathrm{GRm}, 4 \mathrm{~cm}$; $\mathrm{Gm}$, formed of $2-5 \mathrm{~cm}$ pebbles with common subangular and angular limestone fragments), with scours of medium gravel that cut the top of II-u and a concentration of angular 
limestone fragments at the base, (6) Mmy, with few deformed sand intercalations, and irregular load-casts and small pillars at the base, (7) Sml with iron-oxide mottles and an erosive lower boundary.

\subsubsection{Sub-complex AS4}

Sub-complex AS4 groups the sand layers archeologically named II- $\varnothing$, a set of beds at the base of sub-complex AS3 preserved from erosion against the back wall (Fig. 6) and following, from top, the sequence Sfm, Sfm, Sfl, Sml, Lmy, Sfm, Sfl, Sml. The base is a paraconcordant surface.

\subsubsection{Sub-complex AS5}

Sub-complex AS5 is composed of a ca. 1-m thick sequence of mainly alluvial sediment with a poorly developed buried soil on top, where at least four minor cycles can be recognized (Fig. 6). The base of the sub-complex is a paraconcordant unconformity in the inner part of the rockshelter, while it comes to rest directly on bedrock to the north (Figs. 6 and 7).

The uppermost cycle begins with unit II-u, a poorly developed buried alluvial soil, thickening to the north (outwards); in Trench I, it is clayey silty loam, brown (7.5YR 5/3, moist), with weak prismatic medium structure, firm, low porosity and some organic matter, with weakly recognizable parallel flat lamination, thin ironoxide coating and scarce vegetation pseudomorphs. To the north, the unit was subdivided into four subunits, from top: (1) M, gray, with fine discontinuous lamination, occasional charcoal fragments, sometimes with a lenticular layer of Bcf at the base, (2) silty clay dark organic thin layer, with prismatic structure (related to drying), with occasional charcoal fragments, (3) thin layer as (1), and (4) the 'classical' II-u (see description above) but with a vertical color gradient. The basal units of this cycle are: II-w, Bcf; II-y, Sfm; III-a, K.

Below, another cycle is composed of units III-b, Sfl, and III-c, Sfl with a carbonate crust at its lower boundary. In open area excavation, layers III-b, III-c and III-d (often cemented by the carbonate precipitation processes that formed III-c), were indistinguishable, and, as such, dug as a single unit, called III-b/d. Underneath, a third sequence is present and articulates as follows: III-d, fine to coarse sand with some randomly distributed and oriented heterometric limestone fragments, yellowish brown (10YR 5/4, moist), structureless, chaotically arranged, with few oxidized mottles, common bone fragments and lithic artifacts, lower boundary sharp, slightly wavy; III-e, Sml; III-f, Sml; III-g, Sml; III-h, K.

The bottom cycle of sub-complex AS5 is articulated as follows (see Fig. 5): III-i, Sml, locally containing a Bcf discontinuous lenticular layer; III-j, fine to coarse sand with some randomly distributed and oriented heterometric limestone fragments, yellowish brown (10YR 5/4, moist), structureless, with common bone fragments and lithics, locally containing a Bcf discontinuous lenticular layer (note that, in open area excavation, layers III-i and III-j were undistinguishable and, as such, dug as a single unit, called III-i/j, with subdivisions where observed; see Fig. 5); III-k, Sml, the lower boundary being either erosive, with small pebbles or limestone fragments dispersed on the surface, or corresponding to a carbonate crust; III-l, discontinuous lenses of $\mathrm{Bcm}$ with a carbonate crust at base, passing to Sfl with chaotic intercalations of Bcf (at places matrix-supported), including large (dm-sized) limestone fragments, to the $\mathrm{N}$ and $\mathrm{W}$; III-m, Sfl with some intercalations of Sml on top; III-n, Sml with abrupt erosive boundary and some limestone fragments, large (dm-sized) at the base, where they are embedded in the top of unit IV.

\subsection{Unit $I V$}

The extant bottom of the Cueva Antón succession is the archeologically sterile unit IV (Figs. 6 and 7). The unit is dark grayish brown silty clay sediment, firm (over-consolidated), with weakly recognizable horizontal stratification; shiny faces occur, and rootlets and carbonate nodules are present in its uppermost part. Occasional charcoal fragments and terrestrial snails are present, as well as vegetal tissue pseudomorphs. The unit has been recognized over a thickness of $\sim 1 \mathrm{~m}$ but its lower boundary has not yet been reached.

\section{Micromorphology}

In thin section, the Cueva Antón sediments exhibit the same, clear facies differentiation observed in the field. An obvious distinction exists between the units classified as coarser, sand facies and the finer ones (see Table 1). Microscopically, both facies show sedimentary and post-depositional characteristics that can be easily linked to alluvial dynamics, even without falling into interpretive statements. Alluvial features are less preserved in other thin sections, particularly those collected from unit II-u and the layers with higher archeological find concentrations, III-d and III-i/j. For descriptive purposes, the samples were clustered in four groups, whose main micromorphological characteristics are summarized in this section; systematic descriptions, arranged in stratigraphic order, can be found in Tables 4 and 5.

\section{Table 4}

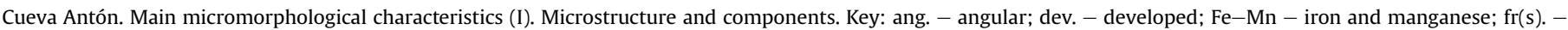
fragment(s); loc. - locally; lst - limestone; mod. - moderate/ly; o.m. - organic matter; OP - orientation pattern; TS - thin section.

\begin{tabular}{|c|c|c|c|c|c|}
\hline Unit & $\begin{array}{l}\text { Sub-unit/ } \\
\text { facies }\end{array}$ & Structure & Porosity & Coarse components & Fine material \\
\hline \multirow[t]{2}{*}{ II-ñ } & $\begin{array}{l}\text { Disturbed } \\
\text { Lmy }+ \text { Sfl }\end{array}$ & Spongy, loc. channel & $\begin{array}{l}\text { Mod. (c.10\%): channels (loc. common), } \\
\text { vertical planes, vughs, chambers, vesicles }\end{array}$ & $\begin{array}{l}\text { Silt to fine sand, c. } 75 \% \text { carbonate \& c. } 25 \% \text { non-carbonate } \\
\text { (see text for details); lithorelicts (see text) }\end{array}$ & Calcitic clay \\
\hline & Lmy & $\begin{array}{l}\text { Mod. to poorly dev. } \\
\text { ang. blocky }\end{array}$ & $\begin{array}{l}\text { Low (c. } 5 \%) \text { : fine planes, channels, } \\
\text { chambers }\end{array}$ & $\begin{array}{l}\text { Silt grains, c. } 75 \% \text { carbonate \& c. } 25 \% \text { non-carbonate } \\
\text { (see text); rare subangular carbonate medium sand; loc. } \\
\text { few silt-sized o.m. frs. }\end{array}$ & Calcitic clay \\
\hline II-p & Lly & $\begin{array}{l}\text { Mod. to well dev. } \\
\text { ang. blocky }\end{array}$ & $\begin{array}{l}\text { Low (c.5\%): fine planes, few channels } \\
\text { and rare chambers }\end{array}$ & $\begin{array}{l}\text { Regular alternations of silty-clay beds \& sandy beds } \\
\text { (see text), rare bone frs. and o.m. frs. }\end{array}$ & Calcitic clay \\
\hline \multirow[t]{3}{*}{ II-u } & Upper & Mod. dev. ang. blocky & $\begin{array}{l}\text { Low (c.5\%): planes, few channels } \\
\text { and rare chambers }\end{array}$ & $\begin{array}{l}\text { As II-u mid sub-unit (except for poorly dev. bedding \& } \\
\text { rare o.m. frs.) }\end{array}$ & $\begin{array}{l}\text { calcitic clay and } \\
\text { micrite areas }\end{array}$ \\
\hline & mid & $\begin{array}{l}\text { Mod. to well dev. } \\
\text { subang. blocky }\end{array}$ & $\begin{array}{l}\text { Mod. (10-15\%): common fine planes } \\
\text { \& channels, few vughs \& chambers }\end{array}$ & $\begin{array}{l}\text { Bedded succession of silt \& fine sand, c. } 75 \% \text { carbonate \& } \\
\text { c. } 25 \% \text { non-carbonate (see text for details); few o.m. frs.; } \\
\text { rare bone frs.; few coarse ang. frs. of local lst, randomly } \\
\text { arranged or with vague horizontal OP }\end{array}$ & \\
\hline & Lower & Spongy to vughy & $\begin{array}{l}\text { Mod. (c.10\%): channels (loc. common), } \\
\text { moldic voids, vughs, few fine planes }\end{array}$ & $\begin{array}{l}\text { Silty to very fine sand, c. } 75 \% \text { carbonate } \& \text { c. } 25 \% \\
\text { non-carbonate (see text); common silt-sized o.m. frs.; } \\
\text { rare ang. coarse frs. of local lst, with inclined OP }\end{array}$ & $\begin{array}{l}\text { calcitic clay and } \\
\text { micrite areas }\end{array}$ \\
\hline
\end{tabular}


Table 4 (continued)

\begin{tabular}{|c|c|c|c|c|c|}
\hline Unit & $\begin{array}{l}\text { Sub-unit/ } \\
\text { facies }\end{array}$ & Structure & Porosity & Coarse components & Fine material \\
\hline III-C & Sml & Bridged grain & $\begin{array}{l}\text { Mod.: common packing voids, few } \\
\text { channels, rare chambers }\end{array}$ & $\begin{array}{l}\text { Fine to medium sand with composition as III-e; coarser, } \\
\text { ang. \& subang. frs. of local lst (c. } 20 \% \text { of total coarse } \\
\text { components), often with horizontal OP }\end{array}$ & $\begin{array}{l}\text { absent (some } \\
\text { micrite) }\end{array}$ \\
\hline III-d & (arch) & Single grain & High (c. $35 \%$ ): only packing voids & $\begin{array}{l}\text { Heterogenous frs. of local lst, chaotically arranged (some } \\
\text { horizontal OP at base), c. } 3 / 4 \text {; sand with same composition } \\
\text { as III-e, c. } 1 / 4 \text {; small frs. of burnt bones and rare frs. of burnt } \\
\text { amorphous o.m. }\end{array}$ & absent \\
\hline III-e & Sml & $\begin{array}{l}\text { Single grain, locally } \\
\text { bridged \& pellicular } \\
\text { grain }\end{array}$ & $\begin{array}{l}\text { Mod. (c. 15\%): mostly packing voids, } \\
\text { rare fine channels }\end{array}$ & $\begin{array}{l}\text { Medium sand composed of c. } 90 \% \text { of carbonate components } \\
\text { and c. } 10 \% \text { of non-carbonate components (see text); larger } \\
\text { grains (c. } 2 \mathrm{~mm} \text { ) at lower boundary; rare charcoal frs. and } \\
\text { bone frs. on top }\end{array}$ & $\begin{array}{l}\text { Absent (some } \\
\text { micrite bridging } \\
\text { or coating grains) }\end{array}$ \\
\hline III-f & Sml & & & Medium to coarse sand, laminated, components as III-e & \\
\hline III-g & Sml & & & Medium sand, components as III-e & \\
\hline III-g & $\mathrm{Sml} / \mathrm{Sfl}$ & $\begin{array}{l}\text { Single grain, bridged } \\
\text { grain in fine sand beds }\end{array}$ & $\begin{array}{l}\text { Mod. (c. } 8 \% \text { ) in fine sand beds to high } \\
\text { (c. } 18 \% \text { ) in coarse sand beds: mostly } \\
\text { packing voids with few horizontally } \\
\text { elongated vughs }\end{array}$ & $\begin{array}{l}\text { Regular alternations of fine, medium and coarse sand beds; } \\
\text { sand with composition as III-e; larger ang. frs. of local lst } \\
\text { in variable quantity (but always subordinate) }\end{array}$ & Absent \\
\hline III-i & $\mathrm{Sfm} / \mathrm{l}+\mathrm{K}$ & $\begin{array}{l}\text { Bridged grain to pellicular } \\
\text { or single grain }\end{array}$ & $\begin{array}{l}\text { mod. (c. } 10 \% \text { ): mostly packing voids } \\
\text { with rare vughs }\end{array}$ & $\begin{array}{l}\text { Coarse silt to fine sand, c. } 80 \% \text { of carbonate components } \\
\& \text { c. } 20 \% \text { of non-carbonate components }\end{array}$ & $\begin{array}{l}\text { Absent (some } \\
\text { micrite) }\end{array}$ \\
\hline IV & & $\begin{array}{l}\text { Poorly to mod. dev. } \\
\text { ang. blocky }\end{array}$ & $\begin{array}{l}\text { Low (c. } 5 \% \text { ): fine planes, channels, } \\
\text { chambers, vesicles \& moldic voids }\end{array}$ & $\begin{array}{l}\text { Silt to very fine sand, c. } 75 \% \text { carbonate } \& \text { c. } 25 \% \\
\text { non-carbonate (see text); rare coarse frs. of shell }\end{array}$ & Calcitic clay \\
\hline
\end{tabular}

Table 5

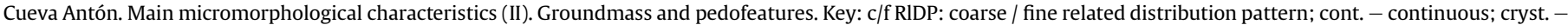
calcitic crystallitic; disc. - discontinuous.

\begin{tabular}{|c|c|c|c|c|c|}
\hline Unit & Sub-unit/facies & c/f RIDP & b-fabric & Pedofeatures features & $\begin{array}{l}\text { Sedimentary features and } \\
\text { remarks }\end{array}$ \\
\hline II-ñ & $\begin{array}{l}\text { Disturbed } \\
\text { Lmy }+ \text { Sfl }\end{array}$ & Open to single spaced porphyric & Poorly dev. cryst. & $\begin{array}{l}\text { Common biogenic dense complete infillings; micrite } \\
\text { coatings on voids; depletion areas; Fe-Mn pedofeatures as } \\
\text { Lmy facies (see below) }\end{array}$ & Poorly sorted, well packed \\
\hline & Lmy & Fine monic to open porphyric & $\begin{array}{l}\text { Poorly dev. cryst., } \\
\text { dotted }\end{array}$ & $\begin{array}{l}\text { Fe-Mn: typic nodules, disc. coatings \& loose cont. infillings, } \\
\text { often associated with Fe-rich clay hypocoatings; micrite: } \\
\text { coatings \& hypocoatings in voids, typic nodules sometimes } \\
\text { rich in o.m. punctuations; common biogenic infillings; } \\
\text { depletion areas }\end{array}$ & Poorly sorted, well packed \\
\hline II-p & Lly & $\begin{array}{l}\text { Enaulic to chitonic (coarser beds), } \\
\text { open porphyric (finer beds) }\end{array}$ & Poorly dev. cryst. & $\begin{array}{l}\text { Fe-Mn: common nodules into groundmass with Fe } \\
\text { hypocoating, loose cont. infillings, coatings on channels } \\
\text { with Fe hypocoatings; micrite: coatings on planes \& grains, } \\
\text { dense complete infillings in planes, irregular nodules in } \\
\text { coarser beds }\end{array}$ & $\begin{array}{l}\text { Bedded sequence with } \\
\text { normal grading, parallel \& } \\
\text { flaser lamination; mod. } \\
\text { (coarser beds) to well } \\
\text { sorted (finer beds), mod. } \\
\text { (coarser beds) to well } \\
\text { packed (finer beds) }\end{array}$ \\
\hline II-u & upper & $\begin{array}{l}\text { Enaulic (loose beds), single spaced } \\
\text { to close porphyric (dense beds) }\end{array}$ & $\begin{array}{l}\text { Poorly dev. cryst., } \\
\text { dotted }\end{array}$ & $\begin{array}{l}\text { Few biogenic loose disc. infillings; few Fe-Mn typic nodules } \\
\text { with hypocoatings \& coatings on voids; common micrite } \\
\text { coatings on voids }\end{array}$ & $\begin{array}{l}\text { Weakly bedded; well } \\
\text { sorted, mod. (loose beds) to } \\
\text { well packed (dense beds); a }\end{array}$ \\
\hline & mid & & & $\begin{array}{l}\text { Fe-Mn: few typic \& dendritic nodules, loose cont. infillings, } \\
\text { coatings on biogenic voids, often associated with } \\
\text { hypocoatings (see text); micrite: common coatings, } \\
\text { hypocoatings \& infillings in planes \& channels; few loose } \\
\text { cont. infillings (several generations); common crescent bow } \\
\text { like fabrics }\end{array}$ & $\begin{array}{l}\text { stone-line of coarse sand } \\
\text { and lst frs. enriched in } \\
\text { micrite is found between } \\
\text { the sub-units }\end{array}$ \\
\hline & lower & Open to double spaced porphyric & & $\begin{array}{l}\text { Fe-Mn: common typic nodules, coatings on voids } \\
\text { accompanied by hypocoatings, dendritic nodules, } \\
\text { occasionally accompanied by hypocoatings; frequent } \\
\text { biogenic dense cont. infillings with bow like fabric (several } \\
\text { generations); depletion areas }\end{array}$ & $\begin{array}{l}\text { Weakly bedded; poorly } \\
\text { sorted, well packed }\end{array}$ \\
\hline III-c & & Gefuric to chitonic & Poorly dev. cryst. & $\begin{array}{l}\text { Micrite: common bridges and rare hypocoatings around } \\
\text { grains (particularly calcite crystals and sparry limestone); } \\
\text { rare passage/fabric pedofeatures on channels }\end{array}$ & $\begin{array}{l}\text { Mod. sorted, almost well } \\
\text { packed }\end{array}$ \\
\hline III-d & $(\operatorname{arch})$ & Coarse monic & - & $\begin{array}{l}\text { Almost absent: rare micrite bridges among grains and } \\
\text { intercalations at base }\end{array}$ & $\begin{array}{l}\text { Poorly sorted, weakly } \\
\text { packed }\end{array}$ \\
\hline III-e & Sml & $\begin{array}{l}\text { Mostly coarse monic, few gefuric } \\
\text { and chitonic areas }\end{array}$ & Poorly dev. cryst. & $\begin{array}{l}\text { Very rare: irregular micrite nodules, hypocoatings in small } \\
\text { channels \& around grains (in particular on calcite crystals } \\
\text { and sparry lst) }\end{array}$ & $\begin{array}{l}\text { Erosive lower boundary, } \\
\text { marked by larger }(2-5 \mathrm{~mm}) \\
\text { grains and aggregates (cfr } \\
\text { lithorelicts); well sorted, } \\
\text { mod. to almost well packed }\end{array}$ \\
\hline III-f & Sml & & & Pedofeatures as in III-e & $\begin{array}{l}\text { Well bedded; sorting \& } \\
\text { packing variable }\end{array}$ \\
\hline III-g & Sml & & & Pedofeatures as in III-e & $\begin{array}{l}\text { Well sorted, mod. to almost } \\
\text { well packed }\end{array}$ \\
\hline
\end{tabular}


Table 5 (continued)

\begin{tabular}{|c|c|c|c|c|c|}
\hline Unit & Sub-unit/facies & c/f RIDP & b-fabric & Pedofeatures features & $\begin{array}{l}\text { Sedimentary features and } \\
\text { remarks }\end{array}$ \\
\hline III-g & $\mathrm{Sml} / \mathrm{Sfl}$ & Monic and enaulic areas & - & $\begin{array}{l}\text { Few } \mathrm{Fe}-\mathrm{Mn} \text { oxide coating and nodules at base; very rare } \\
\text { micrite hypocoating around grains and intercalations }\end{array}$ & $\begin{array}{l}\text { Well sorted, mod. (coarser } \\
\text { beds) to well packed (finer } \\
\text { beds) }\end{array}$ \\
\hline III-i & $\mathrm{Sfm} / \mathrm{l}+\mathrm{K}$ & $\begin{array}{l}\text { Gefuric to chitonic, few coarse } \\
\text { monic areas }\end{array}$ & Poorly dev. cryst. & $\begin{array}{l}\text { Micrite bridges \& coatings around grains; rare } \mathrm{Fe}-\mathrm{Mn} \text { oxide } \\
\text { nodules }\end{array}$ & $\begin{array}{l}\text { Very well sorted, almost } \\
\text { well packed }\end{array}$ \\
\hline IV & & Single spaced to open porphyric & (See text) & $\begin{array}{l}\text { Few biogenic loose disc. infillings; common micrite } \\
\text { impregnative nodules, sometimes large, irregularly shaped; } \\
\text { few clay coatings and rare calcitic clay coatings }\end{array}$ & $\begin{array}{l}\text { Mod. sorted, very well } \\
\text { packed }\end{array}$ \\
\hline
\end{tabular}

\subsection{Sand facies}

The microscopic observation of the sand units shows that they are made up of clast-supported sand, which is often laminated, and whose components are mainly subrounded and subangular carbonate clasts (Fig. 8a; see also Fig. 8b). They include (Fig. 8c and d) common fragments of micritic limestone (various sub-types are observed, with more or less organic-rich micrite, sometimes featuring halos of former fossils, algae or oncoids, and fine matrix- supported calcarenite with micritic matrix), fine clast-supported calcarenite, fossiliferous limestone and sparry limestone; fragments of fossil and calcite crystals are also seen.

Non-carbonate components are subordinate and include: few fragments of microcrystalline chert (Fig. 8c and d); occasional mono- and polycrystalline quartz; rare feldspars, fragments of metamorphic rocks, and very rare colored minerals (among them amphiboles, pyroxenes, occasional micas and probable glauconite). These siliciclastic components show the same grain size as that of
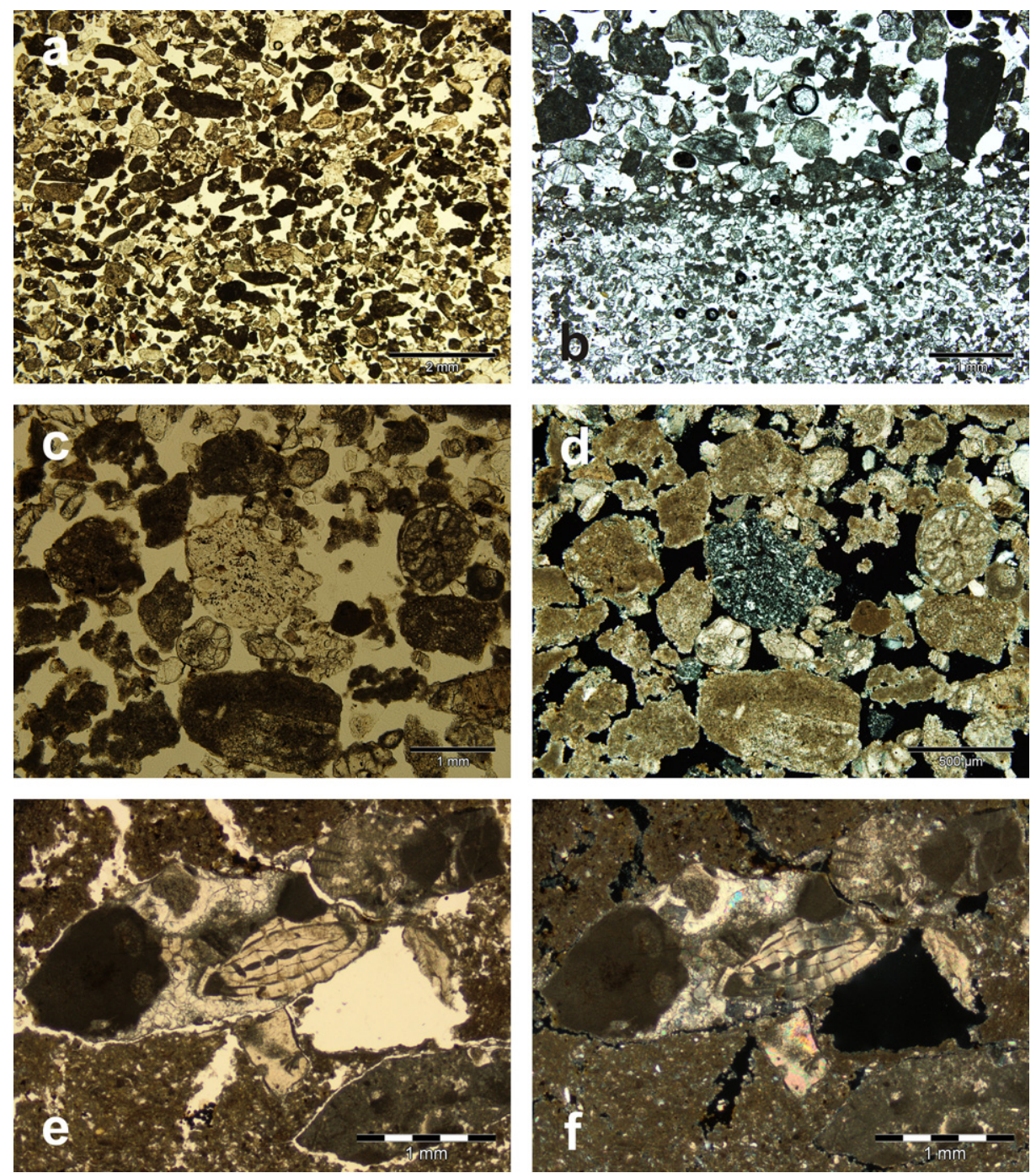

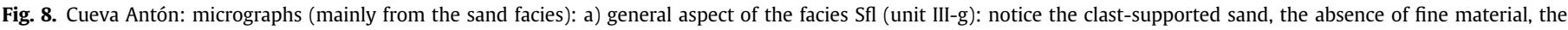

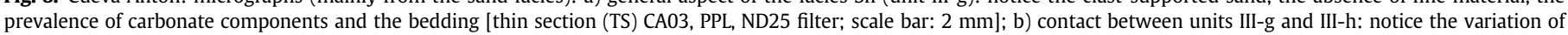

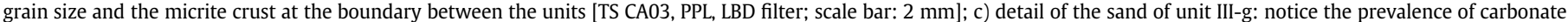

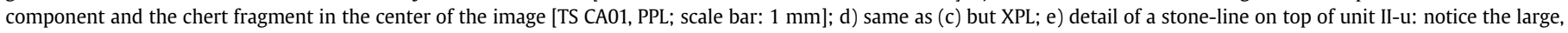
angular, horizontal limestone fragments [TS CA06, PPL; scale bar: $1 \mathrm{~mm}$ ]; f) same as (e) but XPL. 
the carbonate components, are mostly subrounded or subangular, and do not show any weathering except for feldspars, which sometimes are weakly altered.

Larger, angular or subangular fragments of local bedrock, coming from the cave wall and roof, are present in variable amounts, usually scarce (Fig. 8e and f; see also Fig. 10d and e). The limestone fragments are often horizontally oriented and sometimes exhibit algal mat or patina on one side.

Fine material is scarce or even absent in the sand facies (see, e.g., Fig. 8a, $\mathrm{c}$ and $8 \mathrm{~d}$ ). Features related to soil formation are almost nonexistent: microstructure is mainly single, bridged or pellicular grain, while pedofeatures are poorly represented and often limited
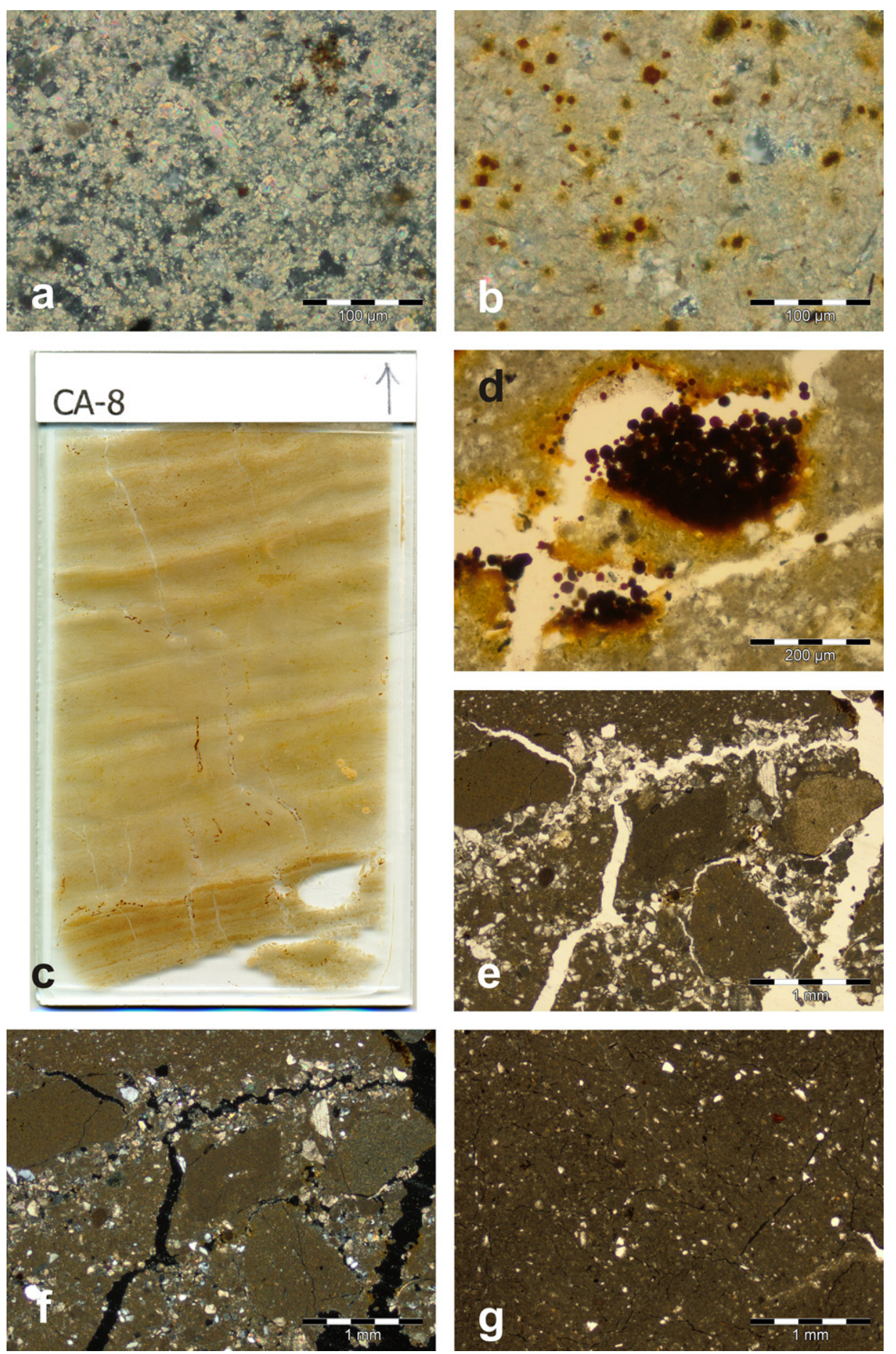

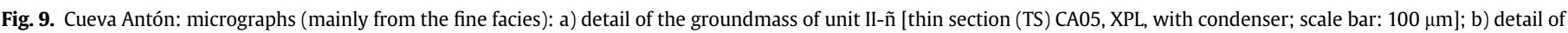

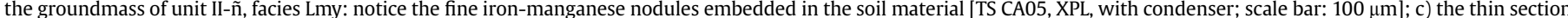

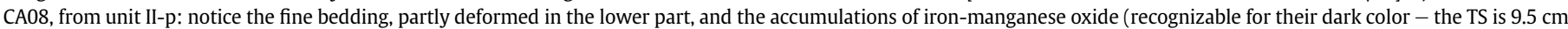

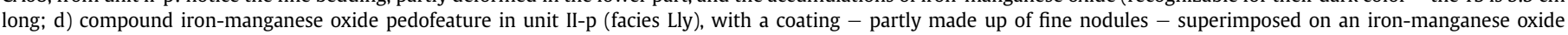

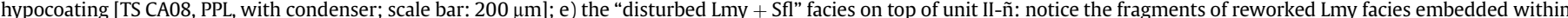

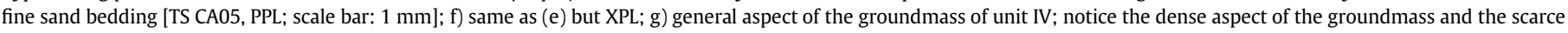
silt to fine sand grains [TS CA04, PPL; scale bar: $1 \mathrm{~mm}$ ]. 
to micrite accumulation between grains. The good preservation of bedding/lamination, which is easily recognized both in the field and in thin section, is further evidence of the reduced impact of post-depositional dynamics.

Micrite crusts often mark the contact between units of different grain size; also observed in the field, they are easily detected under the microscope (Fig. 8b). The crusts are thin $(200-500 \mu \mathrm{m})$, discontinuous intercalations of micrite filling all the voids, often associated with few fine iron-manganese oxide punctuations (as in unit III-c) or partly enriched in organic matter. Some (e.g., that between units III-g and III-h) may show discontinuous ironmanganese oxide micropans on top.

The description of the thin sections from the sand facies could in fact be done in terms of sedimentary petrology, due to the virtual absence of pedogenetic traits. From such a sedimentological perspective, most of the sand facies from Cueva Antón would be classified as calcarenites.

\subsection{Fine (clay and silt) facies}

In thin section, the finer units appear to be formed by silt and clay, with intercalated thin beds of fine sand. The coarse components detected in these facies are mostly carbonate (Fig. 9a), while non-carbonate components (quartz, feldspars, micas) are scarcer than in the sand facies, even if their relative proportions are the same. Organic matter may occur as coarse material, occasionally showing cell structures, and as dark fine material, in form of punctuations, cells, cell tissues and amorphous fine organic matter. In most samples, the fine material is micrite-enriched clay ("calcitic clay", in Table 4).

The units of Lmy and Lly facies show the same mineralogy and grain size but present distinct microstructure and sedimentary features: whereas the Lly facies is organized into well preserved, normally graded laminated cycles (Fig. 9c), the units of Lmy facies display evidence of biological disturbance (in particular burrowing) and of mechanical disruption. Some post-depositional features are common to both facies and include: micrite accumulation, in the form of hypocoatings, coatings, or infillings (Table 5), the latter mostly in the coarser beds; iron-manganese concentrations (such as dark brownish red typic nodules, 4$40 \mu \mathrm{m}$; Fig. 9b), discontinuous coatings on voids, and loose continuous infillings (often made up of small nodules and associated with halos of orange iron-oxide hypocoating; Fig. 9d). Biogenic pedofeatures are more common in the Lmy facies and include loose continuous or discontinuous infillings and dense complete infillings, often with crescent fabric. The dense complete infillings usually fill channels with a vertical axis and exhibit a gradual external boundary. According to Kooistra and Pulleman (2010), these features may be related to a single animal passage through wet sediment: they are probably burrows, penecontemporaneous with deposition and produced by the action of riverine mollusks within a waterlogged sediment.

The Lly facies is represented in unit II-p (thin section CA-08, see Fig. 9c), where regular alternations of finer and coarser beds appear. The finer beds mostly consist of clay material enriched in micrite, with poorly developed calcitic crystallitic b-fabric, which embeds occasional non-carbonate silt grains and fine fragments of probable humified organic material. The coarser beds are silt to medium sand with dominant carbonate components and subordinate noncarbonate constituents. Bone fragments are present, even if their subrounded shape and their size, consistent with the grain size of the surrounding sediment, indicate secondary deposition as transported particles. The Lly beds show typical traction sedimentary features such as grading, parallel lamination and flaser bedding (Fig. 9c).
The Lmy facies are mostly composed of fine material with micrite, rare microsparite $(5-20 \mu \mathrm{m})$, organic punctuations, as well as occasional silt grains scattered within the micromass. The microstructure is angular blocky and seems to derive from desiccation rather than proper soil formation processes.

In the upper part of unit II-ñ (thin section CA-05), microscopic observation detected a facies not recognized in the field. This facies is a mix of silt and sand material ("disturbed Lmy + Sfl" in Tables 4 and 5), where fragments of both facies are chaotically mingled. The occurrence of biological pedofeatures indicates that this unit derives from the syn-depositional disruption of Sfl and Lmy beds through mechanical disturbance (e.g., trampling and burrowing see Fig. 9e and f). Other pedofeatures are similar to those observed in the other fine facies (see Tables 4 and 5) but for the likely presence of depleted areas. Large lithorelicts occur in this facies and also in the Sfl bed found at the base of unit II-ñ. The lithorelicts are sand-sized $(0.25-2 \mathrm{~mm})$ fragments of silty-clay sediment similar to facies Lly, partly phosphatized (as indicated by autofluorescence observation), and resemble alluvial mud balls.

The microscopic characteristics of unit IV are similar to those of the above-mentioned fine facies. Its grain size is mostly fine, with silt to very fine sand grains embedded within micrite-enriched clay material. The components are mainly carbonate, with scarce non-carbonate grains and few fragments of organic matter, the largest being sand-sized and showing cell internal structure; the microstructure is angular blocky, with low porosity and dense, highly homogenized, intrapedal material. However, other microscopic features are exclusive to unit IV: the higher degree of weathering of some components, in particular feldspars; the bfabric, which is calcitic crystallitic but locally undifferentiated and striated, which could be induced by shrink-swell dynamics; the presence of light-colored, whitish (in PPL) clay coatings with sharp extinction, locally with microsparite and micrite hypocoatings; and the occurrence of impregnative nodules, iron pseudomorphs after plant tissue and moldic voids and vesicles, as well as fragments of gastropod shells.

\subsection{Unit II- $u$}

Unit II- $\mathrm{u}$ is very similar to the fine facies described above, as far as its grain size and mineralogy are concerned, although with significant lateral variation (e.g., its upper part is coarser and shows some bedding towards the exterior). Among the coarse components, a few silt to fine sand grains are found, as well as reworked fragments of bone and coarser angular fragments of local limestone. A stone-line of limestone fragments is visible in the thin section CA-06. However, other features indicate that the unit was exposed to stable conditions for a longer time span than the fine facies mentioned above - not long enough, however, to form a proper soil horizon. Some such micromorphological traits were observed in thin sections: more intense (and prolonged) bioturbation, which partly homogenized the groundmass and led to the incorporation of organic matter into the fine material (Fig. 10a and b); moderately developed blocky structure and higher, moderate porosity, mostly consisting of fine planes and channels; rare occurrence of orange limpid clay areas; and the presence of compound pedofeatures, with micrite hypocoatings and infillings superimposed over iron-manganese coatings in planes and channels.

6.4. Layers with higher concentrations of archeological finds: units III-d and III-i/j

The Cueva Antón deposit contains an abundant Middle Paleolithic archeological record: lithic artifacts, faunal remains, and 
charcoal fragments. Archeological fieldwork has shown that the finds, however, are unevenly distributed across the succession, most probably because human occupation occurred at distinct points in space and time, was infrequent and short, and underwent very little post-depositional disturbance. These factors explain the patchiness of the record: some units can be rather poor in a specific sector and quite rich at a few meters' distance. The layers where an archeological record is present are mostly those in sub-complex AS5, beginning at the top with unit II-u, which yielded scant artifacts, and ending at the bottom with unit III-i/j, with abundant remains and well preserved habitation features, namely a number of hearths which were uncovered in 2011 and 2012. Artifacts and an ecofactual context indicating an actual occupation of the shelter (as opposed to transport and accumulation by fluvial action) have also been recovered in units II-l and I-k.

The patchy nature of the site's archeological record is also apparent in thin section. Anthropogenic characteristics, both direct and indirect, are scarce in the thin sections from Cueva Antón, even if most of the collected samples contain occasional bone fragments, sometimes burnt and often reworked (Fig. 10c), and rare fragments of charcoal or burnt organic matter (Table 4). The latter may also derive from natural processes, although the layers with higher concentrations of wood charcoal are those where human occupation is documented, with only a few fragments produced by natural fires or derived from the reworking of soils upstream of the site being present in the other units (Badal et al., 2012).

Two of the archeologically richest layers of the lowermost subcomplex (AS5), units III-d and III-i/j, were analyzed. These layers appear as sandy sediment with the same composition of the nonanthropized sand facies (see, e.g., Fig. 5 for archeological unit III-i/ j) except for the more common presence of fragments of local limestone and the occurrence (rare, in any case) of human or biological inputs (silt- and sand-sized fragments of burnt bones and charcoal, and silt-sized fragments of burnt, amorphous organic matter). The main difference with respect to the other sand layers lies in the overall organization of the groundmass. Even if some platy components may show horizontal orientation, the general aspect of the sediment lacks any form of sedimentary organization: coarse components are less sorted than the constituents of other units and unevenly distributed and oriented; packing is low; porosity is high (about 35\% in unit III-d, see Fig. 10d); no pedofeatures were detected, except for some micrite crusts and bridges at the top and base of unit III-d (Fig. 10e); no lamination or bedding were observed. Thus, the most diagnostic micromorphological trait of such units is the absence of the sedimentary features and stratigraphic organization that are apparent in the other sand units of the alluvial succession. Some deformation features and biogenic pedofeatures observed in other units are absent, suggesting that the destruction of the 'typical' alluvial characteristics of the sand facies is due to syndepositional processes, not to post-depositional dynamics.

\section{Discussion}

\subsection{Nature of the Cueva Antón succession: sedimentary processes and environment}

The fill of Cueva Antón is mainly composed of two groups of sediments and related facies: (1) water-lain sediments (facies G, GR, S, L and M) and (2) deposits accumulated by gravitational or slope processes (facies B - see Table 1). Middle Paleolithic human occupations are embedded in both types of sediments or intercalated between them. The first group of sediments constitutes the main bulk of the deposit, which, essentially, is an alluvial succession: a Pleistocene fluvial terrace whose characteristics (bedding, sedimentary features and lateral variation of facies) were preserved in pristine form inside the rockshelter.

The prime alluvial origin of the deposit is demonstrated by several features observed both in the field and under the microscope. Four main types of alluvial sediments were recognized at Cueva Antón, often arranged as sequences or as lateral facies produced by the shifting of distinct fluvial sub-environments (see Tables 1 and 6):

- Gravel (facies GR and G) sedimentary bodies represent lateral bar or channel deposits left by the past activity of the River Mula, their accumulation being the product of the traction activity of river-bottom currents. Gravel facies indicate the ingression of the (paleo-)Mula riverbed inside the rockshelter, during phases of intense fluvial activity.

- Sandy layers (facies Sf and Sm) were laid down by traction water currents through lateral accretion in river bars or natural levees and derive from periodic expansions of the Mula talweg inside the shelter, probably during phases of flooding. These sand facies show bedding, lamination and textural features (e.g. rounding) that are diagnostic of traction currents, while the composition of the sand grains (abundant carbonate lithotypes and subordinate non-carbonate, siliciclastic elements) is exotic to the cave and matches the geology of the present Mula drainage basin (see Fig. 2).

- The fine sediments of the Lm and Ll facies accumulated by decantation of suspended sediment from still or slowly moving water, through vertical accretion, or by alternation of lowenergy traction dynamics combined with decantation of suspended particles, as indicated by such diagnostic features as the flaser bedding observed in layer II-p. These facies are related to low-energy overbank flooding, with mechanisms similar to floodplains or produced by the infilling of abandoned river channels. The $\mathrm{Ll}$ facies shows well preserved bedding (see Fig. 9c). Some of the structureless $\mathrm{Lm}$ facies are derived from the disturbance of former bedding by bioturbation or trampling, as visible at the top of unit II-ñ (see Fig. 9e and f). In both cases, the composition of the silt fraction is consistent with that of the sand facies, with dominant carbonate components and subordinate non-carbonate ones.

- Unit II-u shows slightly different characteristics in the field but appears, in thin section, as fully comparable to the fine facies as far as its coarse components and sedimentary arrangement are concerned. Its main differences with the $\mathrm{Ll}$ facies reside in the presence of clay and organic matter in the fine material, the slightly higher development of microstructure, the higher porosity and the larger number and development of pedofeatures. II-u is a poorly developed alluvial soil, formed by the simultaneous action, during a relatively long time span, of fine sedimentation and soil formation, the latter responsible for the micromorphological features mentioned above.

- The fine sediments of $\mathrm{Mb}$ and Mm facies were deposited by decantation of material suspended in still or almost still water, through vertical accretion, with dynamics similar to those of lacustrine environments. Very similar features were observed in the sample from unit IV. It exhibits some characteristics that are typical for sediments from low-energy, paludal, floodplain or abandoned channels ("clay plug"), with decantation of fine material and organic matter, alternating with events of sub-aerial exposure under oxidizing conditions (as indicated, for instance, by the presence of roots and rootlets) and of still water, reducing environment (responsible for mottling and the formation of ironoxide nodules). The possibility that unit IV is the top of a buried upward-fining alluvial sequence cannot be excluded, although more data are needed to understand its formation and age. 
Table 6

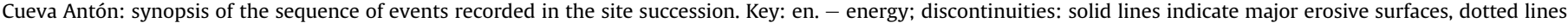
indicate minor discontinuities. Data on approximate age after Zilhão et al., 2010 and Zilhão et al., 2012.

\begin{tabular}{|c|c|c|c|c|c|c|c|c|c|c|c|c|c|}
\hline \multirow[b]{2}{*}{ 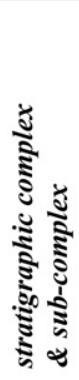 } & \multirow[b]{2}{*}{ 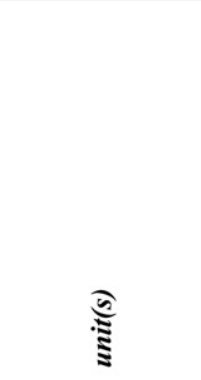 } & \multirow[b]{2}{*}{ 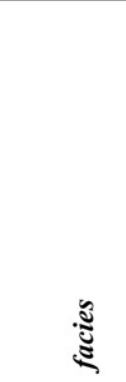 } & \multicolumn{8}{|c|}{ processes } & \multirow[b]{2}{*}{ 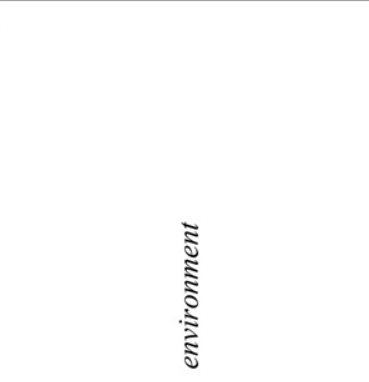 } & \multirow[b]{2}{*}{ 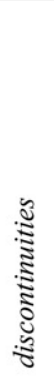 } & \multirow[b]{2}{*}{ 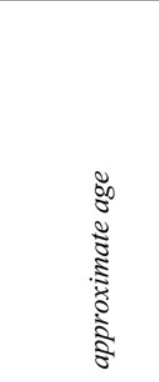 } \\
\hline & & & 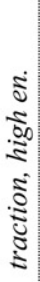 & 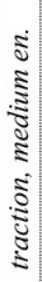 & $\begin{array}{c}5 \\
5 \\
5 \\
5 \\
5 \\
5 \\
5 \\
5 \\
\vdots\end{array}$ & 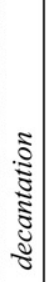 & 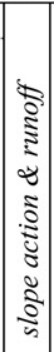 & 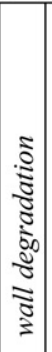 & 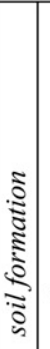 & 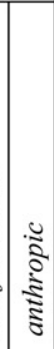 & & & \\
\hline$D D$ & & & & & & & & & & & $20^{\text {th }}$ century artificial reservoir & & post-1929 AD \\
\hline$T L$ & & & & & & & & & & & & & \\
\hline \multirow{9}{*}{$A S I$} & & Bef & & & & & & & & & \multirow{4}{*}{$\begin{array}{l}\text { alluvial floodplain alternating to } \\
\text { wall degradation \& runoff }\end{array}$} & & \\
\hline & & Lmy-b & & & & & & & & & & & \\
\hline & & Bcf & & & & & & & & & & & \\
\hline & & $\mathrm{Lmb}$ & & & & & & & & & & & \\
\hline & $\mathrm{I}-\mathrm{g}, \mathrm{I}-\mathrm{h} \& \mathrm{I}-\mathrm{k}$ & Bcf. Bcm & & & & & & & & & \multirow{5}{*}{$\begin{array}{l}\text { alluvial (floodplain + bar / levee } \\
\text { intercalation \& one lacustrine } \\
\text { event) alternating to (and ending } \\
\text { with) wall degradation \& runoff }\end{array}$} & & \\
\hline & $\mathrm{I}-\mathrm{i}$ & Sfl, Lmy-b & & & & & & & & & & & \\
\hline & $\mathrm{I}-\mathrm{j} \& \mathrm{II}-\mathrm{a}$ & Sfm. M & & & & & & & & & & & \\
\hline & II-c & Bcf & & & & & & & & & & & \\
\hline & II-b & Lmy & & & & & & & & & & & $36.5-38 \mathrm{ka}$ \\
\hline \multirow{11}{*}{$A S 2$} & II-d \& II-e & $\mathrm{Sfl}, \mathrm{Sfm}$ & & & & & & & & & \multirow{5}{*}{$\begin{array}{l}\text { alluvial bar / levee alternating to } \\
\text { wall degradation \& runoff }\end{array}$} & & $55-75 \mathrm{ka}$ \\
\hline & & Bcf & & & & & & & & & & & \\
\hline & II-f & Sfl & & & & & & & & & & & \\
\hline & II-f & Bcf & & & & & & & & & & & \\
\hline & II-f & $\mathrm{Sfl}$ & & & & & & & & & & & \\
\hline & II-g & Bcf & & & & & & & & & \multirow{6}{*}{$\begin{array}{l}\text { fining upward alluvial sequences } \\
\text { (channel, bar \& floodplain) with } \\
\text { intercalated events of wall } \\
\text { degradation }\end{array}$} & & \\
\hline & II-h \& II-i & Lmb-y & & & & & & & & & & & \\
\hline & II-k & Bef & & & & & & & & & & & \\
\hline & II-k (E side) & $\mathrm{Sfl}$ & & & & & & & & & & & \\
\hline & II-l up & B-Bcf & & & & & & & & & & & \\
\hline & II-1 (+ II-m) & $\mathrm{G}, \mathrm{GR}, \mathrm{S}$ & & & & & & & & & & & \\
\hline \multirow{6}{*}{$A S 3$} & II- ñ, II-z \& II-o & $\mathrm{Sfl} / \mathrm{m}, \mathrm{M}$ & & & & & & & & & fining upward alluvial sequence & & \\
\hline & II-p & Lmb & & & & & & & & & wall degradation followed by & - & \\
\hline & II-p & Bef & & & & & & & & & alluvial floodplain & & \\
\hline & II-a & Bef & & & & & & & & & alluvial sequence (canal, bar \& & & \\
\hline & II-s & Lmb & & & & & & & & & floodplain) followed by wall & & \\
\hline & II-t & $\mathrm{G}, \mathrm{GR}, \mathrm{S}$ & & & & & & & & & degradation & & \\
\hline AS4 & II- $\varnothing$ & (varied) & & & & & & & & & alluvial bar / levee & & \\
\hline \multirow{12}{*}{$A S 5$} & III-u & & & & & & & & & & & & \\
\hline & II-w & Bcf & & & & & & & & & alluvial bar / levee with events of & & \\
\hline & II-y & $\operatorname{Sfm}(2)$ & & & & & & & & & Wall degradation \& siope & & $55-75 \mathrm{ka}$ \\
\hline & III-a & Bcf & & & & & & & & & & & \\
\hline & III-b \& III-c & $\operatorname{Sfl}(2)$ & & & & & & & & & alluvial bar / levee & & \\
\hline & III-d & & & & & & & & & & alluvial bar & & \\
\hline & III-e, III-f \& III-g & Sml & & & & & & & & & alluvial bar & & $55-75 \mathrm{ka}$ \\
\hline & III-i & Sml & & & & & & & & & & & \\
\hline & III-j & & & & & & & & & & woll deoradation \& alluvial har & & \\
\hline & III-k & Sml & & & & & & & & & 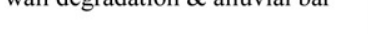 & & \\
\hline & III-1 & $\mathrm{Bcm}$ & & & & & & & & & & & \\
\hline & III-m \& III-n & Sml, Sfl & & & & & & & & & alluvial bar & & $55-75 \mathrm{ka}$ \\
\hline$F P$ & IV & & & & & & & & & & 'lacustrine' & & \\
\hline
\end{tabular}

The alluvial dynamics led to the accumulation of sediments and components that are exotic to the local geological context, while inputs from the cave are scarce, unevenly distributed throughout the succession and mainly found near the cave wall. Local inputs are easily recognized: they are fragments of limestone, often horizontally oriented and much larger than the average grain size of the embedding sediment. Algal mats may cover in part the surface of the limestone fragments. The mats are often observed on the scarce slabs embedded in the sand facies but are usually absent in the layers where the local limestone fragments are dominant. The interpretation of these limestone fragments is not straightforward.
Their morphology often resembles frost slabs, which could denote moderate action of freeze-thaw on cave walls and be a marker of a much colder climate than today during certain phases of the Upper Pleistocene, which is consistent with the site's wood charcoal record (Badal et al., 2012). Some fragments, however, clearly are flakes detached by surface weathering of the cave roof and wall, a process that, even if uncommon, is still active today at Cueva Antón. The distribution and orientation patterns of the Bc facies, which is mostly made up of these coarse inputs from the cave, appear to be related to short-distance slope readjustment of the material and to be controlled by dynamics such as runoff or simple slipping along 

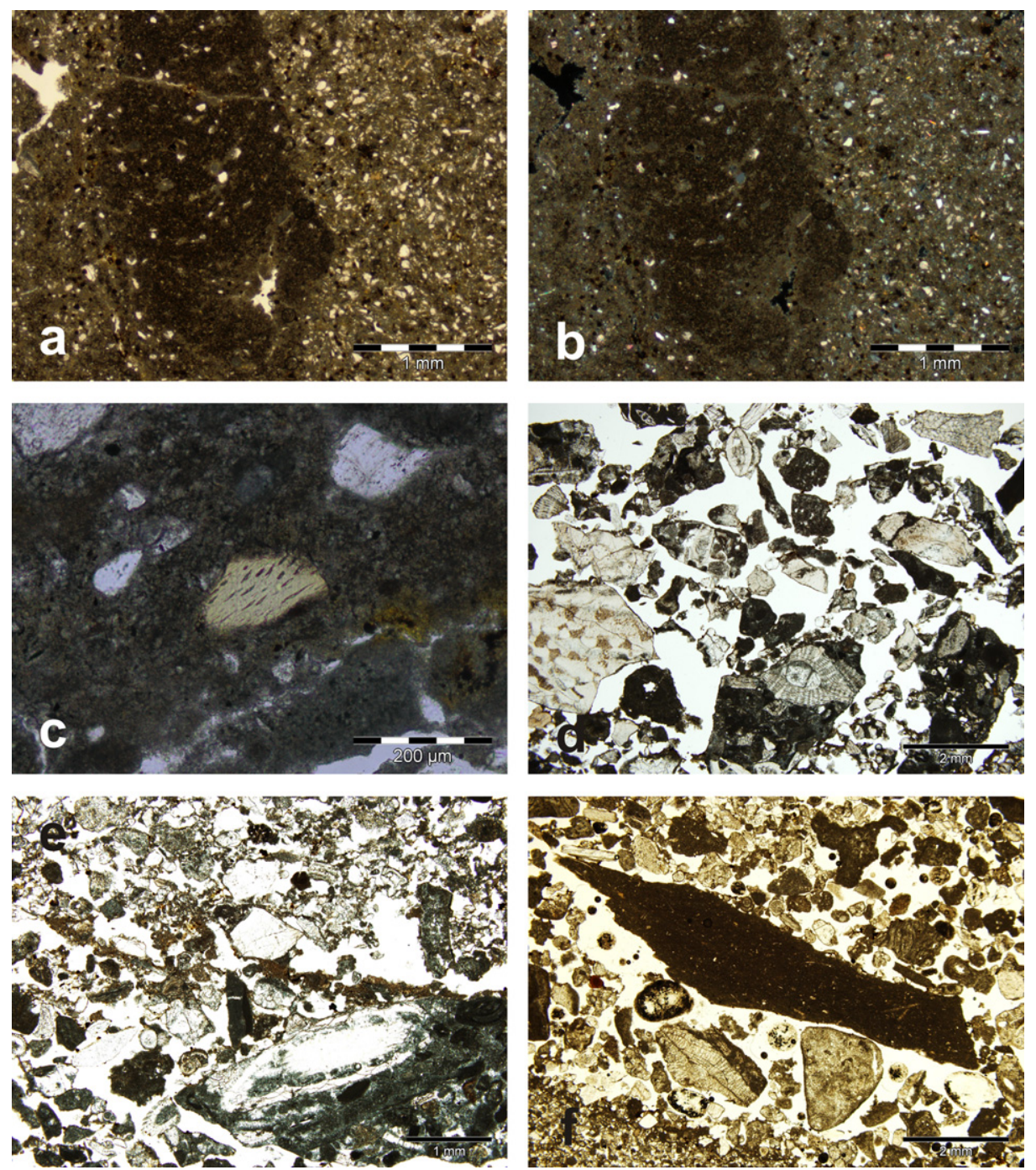

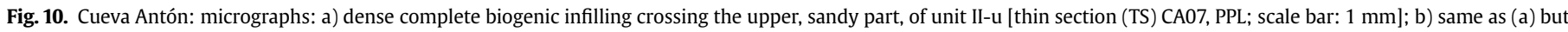

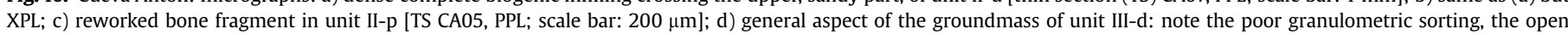

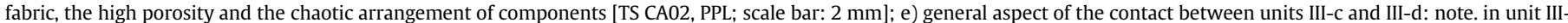

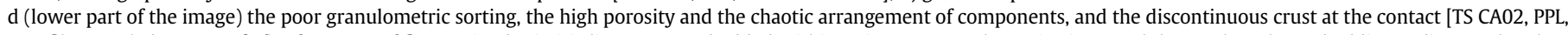

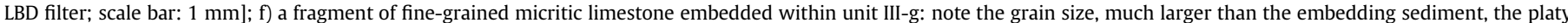

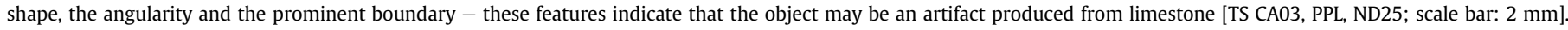

gentle surfaces inside the rockshelter; therefore, this coarse facies indicates phases of fast degradation of the cave wall. It is worth noting, however, that a few limestone fragments observed under the microscope display features that suggest knapped lithic artifacts, even if their conclusive identification as such is not fully supported (Fig. 10f, see also Angelucci, 2010; note that locally available limestone river cobbles were exploited as raw-material by Neanderthals, and especially so in the archeological layers of subcomplex AS5, where they are abundantly represented by chips, flakes, cores and tools).

\subsection{Syn- and post-depositional natural dynamics at Cueva Antón}

One of the most striking microscopic features of the Cueva Antón samples is the overall scarcity of evidence for post-depositional modifications, soil formation or diagenesis; such evidence is limited to pedofeatures due to either micrite accumulation, which are ubiquitous, or the accumulation of iron-manganese oxide, which are mainly restricted to the finer facies. Features related to biological activity (including biogenic microstructure) are scarce as well. The few exceptions are found in unit II-u, a poorly developed alluvial soil (discussed above), and the archeological layers (to be discussed below).

The observed pedofeatures are diagnostic of both sub-aerial and waterlogged environments. Many units of the succession exhibit features that are related to phreatic, or water-saturated in general, environments: the deformed flaser bedding observed in units II-ñ and II-p, the burrows detected in the Lm facies (mainly related to the activity of mollusks), or the superposition of features related to micrite accumulation over iron-manganese oxide coating (e.g. in unit II-u), the latter possibly indicative of a transition from watersaturated to vadose conditions. The almost ubiquitous occurrence of iron-manganese oxide accumulations indicates that, on average, Cueva Antón was, at the time of deposition, a water-saturated, reducing microenvironment. Exceptions are few: unit II-u (whose bioturbation appears to have proceeded through multiple phases) and those layers where trampling or other sub-aerial processes occurred (e.g. the top part of II-ñ). For most units of the AS complex, 
oxidizing, sub-aerial conditions became prevalent only at a later time, perhaps once the incision of the Mula talweg left the Cueva Antón succession high above the stream bed, out of reach for the action of fluvial dynamics.

\subsection{Formation processes of the Cueva Antón anthropogenic units}

Thin section observation has revealed that anthropogenic signatures are not common in the Cueva Antón samples. The nature of the succession, formed of fluvial beds that accumulated quite rapidly (as demonstrated by the scant evidence for soil formation processes and post-depositional dynamics) led to prompt burial of the record left by the Neanderthal occupants, explaining the patchiness of both its horizontal and vertical distributions.

In situ anthropic inputs are present in sub-complexes AS5 (archeological field units III-b/d and III-i/j) and AS1 (layer I-k), and non-existent, so far, in sub-complexes AS4 and AS3. In AS2, a low density scatter of stone tools and large mammal bone fragments is found in unit II-l, where it represents the syn-depositional reworking by fluvial action of the remains of, respectively, short visits by humans and a natural riverside faunal assemblage. No anthropic microfacies were observed in the thin sections analyzed so far (new data on this subject will come from the analysis of the samples collected in the 2012 field season, when hearths were excavated in unit III-i/j, and sampled for micromorphology). In these sections, human activity is mainly recognized through the partial destruction of bedding, sedimentary features and fabric, in particular in the sand facies of sub-complex AS5. This is seen in those units that yielded the highest concentrations of artifacts and ecofacts during excavation, while those lacking an archeological record are mostly undisturbed; this contrast indicates that the mixing or destruction of fluvial facies apparent in the archeologically rich deposits is indeed due to human activity, not animal trampling, as they are layer-specific and do not cross sets of layers.

\section{Final remarks}

The stratigraphic succession preserved inside the Cueva Antón rockshelter represents an excellent record of the archeology and Quaternary geology of the middle part of the Upper Pleistocene of south-east of Iberia. The deposit can be described as a fluvial terrace preserved in almost pristine condition due to (a) the continuous accumulation of alluvial beds and the relatively high accumulation rate, which preserved sedimentary facies and archeological elements from active surface dynamics, (b) the protective effect of the rockshelter, which limited post-depositional dynamics and soil formation processes, and (c) the incision of the River Mula, which spared the deposit from the subsequent action of fluvial dynamics.

Concerning the last point, the highest elevation reached by the fluvial deposit inside Cueva Antón is $\sim 356.5 \mathrm{~m}$ asl, and the highest gravel unit, layer II-m, lies at $\sim 354.0 \mathrm{~m}$ asl. The data available on the topography of the La Cierva reservoir before construction of the dam indicate that the Mula riverbed was flowing, at this location, at an altitude of $\sim 348 \mathrm{~m}$ asl: the difference in height between the present thalweg and the top of the fluvial deposit at the site is therefore $\sim 8.0 \mathrm{~m}$. These figures suggest that the Cueva Antón deposit, as well as the cemented gravel found a few meters upstream of the rockshelter, correspond to the $+5-7 \mathrm{~m}$ terrace mentioned in the literature (Mather et al., 1995), which can be observed at a number of points in this stretch of the Mula valley. For the latter's terrace staircase as a whole, this interpretation further implies that the terraces preserved at higher elevation (with respect to present riverbed) are older than MIS 4 and that, in this specific reach, the total amount of river incision since MIS 3 is about 7-9 $\mathrm{m}$.
Considering that, upstream of the La Cierva dam, the Mula forms a narrow, deeply incised gorge, these data also suggest that this sector underwent a geomorphological evolution distinct from that described further downstream, where the $+32-36 \mathrm{~m}$ terrace is ascribed to the Upper Pleistocene (Agustì et al., 1990) and the lower ones (e.g., those at $+15 \mathrm{~m}$ and $+5 \mathrm{~m}$ ) to the Holocene (Harvey, 1984; Mather et al., 1995). More data are needed to understand the Quaternary evolution of the Mula drainage basin. Unfortunately, the research on this issue is thwarted by the presence of the La Cierva reservoir and dam, placed at a critical spot, and whose construction, in 1929, was carried out before accurate topographic and geomorphological surveys were possible.

As dating work is still ongoing, assessing the total time span involved in the accumulation of the succession and whether its deposition was continuous or not is still premature. However, the available results, as well as the characteristics of the Middle Paleolithic artifact assemblages, indicate that the succession dates to MIS 4 and MIS 3, probably to the ca. 75-36 ka interval. The minor discontinuities point to the existence of hiatuses; however, the poor evidence for post-depositional modification and soil formation processes inside the individual sub-complex sequences indicate an almost continuous accumulation (allowing for the seasonal, annual or decadal rhythm of alluvial flooding and with the exception of minor episodes of geomorphological stability, as in the case of unit II-u). Some upward-fining sequences of the fluvial succession could be related to paleoflood events such as those reported in the literature for other Iberian Middle Paleolithic sites, namely the Jarama VI rockshelter (Jordá Pardo, 2007). Clearly, however, the Cueva Antón succession mostly accumulated via repeated events of overbank flooding, under a moisture regime less dry than at present, as can be inferred from the abundance of features produced by reducing conditions and by the scarcity of pedofeatures derived from evapotranspiration or, in general, from carbonate precipitation. It remains possible that this is due to local microclimatic factors, in particular the recurrent flooding of the rockshelter by the river, as this is in contradiction with the data on wood charcoal mentioned above (Badal et al., 2012). All this suggests that the river margins may have represented a sort of oasis in this predominantly xeric landscape, made possible by a permanent (and perhaps stronger) water flow.

Except for layer I-k (where the inputs from the shelter's walls and roof are more important than the alluvial ones), the remains of the human occupations are usually found at the contact between distinct units or subunits and in the form of thin lenses. This pattern is a by-product of site formation: fluvial sedimentation took place over repeated cycles, each time burying the objects abandoned by the Neanderthals on the surfaces formed by prior sedimentation episodes. As most beds were laid down by low energy traction or by decantation from still waters (see Table 6), the human occupation remains were not significantly displaced from their original position, or removed from the rockshelter's ground surface (which does not exclude that some silt- or sand-sized objects, the reworked bone fragments observed in thin section, could have been washed into the site from a short distance).

The rapid burial of ground surfaces by periodic flooding thus explains the non-palimpsest nature of the occupations observed inside the AS5 sub-complex, where most archeological layers are synchronous paleosurfaces that have undergone limited postdepositional physical modification (pedoturbation) and represent very short time intervals, ones whose length must be in the order of magnitude of the season, year or decade. In this sense, Cueva Antón will provide a unique opportunity to study the use of space and related Middle Paleolithic behavioral patterns, once additional information on the exact timing of sedimentary accumulation and on the synchronicity between activity areas within a single layer, 
which should come from ongoing dating and stone tool refitting work, become available. At the same time, the ephemeral, shortterm nature and rapid burial of the Neanderthal occupations explain the relative scarcity of direct and indirect anthropogenic signatures in either field or microscopic observation.

This simply reflects the fact that, at the scale of the site as a whole, the density of archeological finds is low, and, therefore, the probability that any will be seen when observing randomly selected parts of the deposit is also low, highlighting a number of interesting paradoxes. At Cueva Antón, (a) the geological evidence is better where the archeological record is poorest, (b) the analysis of the archeological record at the micro scale requires targeted sampling carried out as the excavation proceeds and cannot rely solely on the interpretation and random sampling of stratigraphic sections, (c) where the archeology is richest, the impact of the human occupations, no matter how short and infrequent, suffices to erase the geological signatures indicative of the mode of accumulation. Besides its important substantive contributions to the natural history and the archeology of the Upper Pleistocene of Iberia, this site also makes it abundantly clear how the investigation of these kinds of sites can only be carried out as an operation where earth science and archeology are fully integrated throughout - i.e., as geoarcheology.

\section{Acknowledgments}

Archeological fieldwork and research at Cueva Antón were funded, over the years, by the Fundación Séneca (Murcia), the University of Murcia, the Spanish Ministerio de Ciencia e Innovación (grant HAR2011-24878), the Leakey Foundation, the Dirección General del Medio Natural de la Región de Mucia and the Municipality of Mula, and actively supported by the Museo de Arte Ibérico El Cigarralejo de Mula. The authors are also indebted to El Hogar for their welcome and warmth. Thoughtful reviews by the editor and two anonymous referees are gratefully acknowledged. D. Anesin is a doctoral grantee of the University of Trento.

\section{References}

Agustì, J., Freudenthal, M., Lacomba, J.I., Martín Suárez, E., Nägeli, C.A., 1990. Primeros micromamíferos del Pleistoceno Superior de la Cuenca de Mula (Murcia, España). Revista de la Sociedad Geológica de España 3 (3-4), 289-293.

Angelucci, D.E., 2010. The recognition and description of knapped lithic artifacts in thin section. Geoarchaeology 25, 220-232.

Angelucci, D.E., Anesin, D., 2012. Sedimenti e suoli, natura e cultura. Considerazioni geoarcheologiche sulla genesi delle stratificazioni archeologiche in ambiente montano. In: Brogiolo, G.P., Angelucci, D.E., Colecchia, A., Remondino, F. (Eds.), APSAT 1. Teoria e metodi della ricerca sui paesaggi d'altura. SAP, Mantova, pp.11-25.

Angelucci, D.E., Boschian, G., Fontanals, M., Pedrotti, A., Vergès, J.M., 2009. Shepherds and karst: the use of caves and rock-shelters in the mediterranean region during the Neolithica. World Archaeology 41 (2), 191-214.

Aubry, T., Dimuccio, L.A., Almeida, M., Neves, M.J., Angelucci, D.E., Cunha, L., 2011. Palaeoenvironmental forcing during the Middle-Upper Palaeolithic transition in Central-Western Portugal. Quaternary Research 75, 66-79.

Badal, E., Villaverde, V., Zilhão, J., 2012. Middle Paleolithic wood charcoal from three southern Iberian sites: biogeographic implications. In: Badal, E., Carrión, Y., Macías, M., Ntinou, M. (Eds.), Wood and Charcoal. Evidence for Human and Natural History. SAGUNTUM Extra 13. Universitat de València, València, pp. 13-24.

Bronk Ramsey, C.A., 2009. Bayesian analysis of radiocarbon dates. Radiocarbon 51, 337-360.

Bullock, P.N., Fedoroff, N., Jongerius, G.J., Stoops, G., Tursina, T., Babel, U. (Eds.), 1985. Handbook for Soil Thin Section Description. Waine Research Publishers, Wolverhampton.
Courty, M.A., 2001. Microfacies analysis assisting archaeological stratigraphy. In: Goldberg, P., Holliday, V.T., Ferring, C.A.R. (Eds.), Earth Sciences and Archaeology. Kluwer, New York, pp. 205-239.

Fairbanks, R.G., 2005. Radiocarbon calibration curve spanning 0 to 50,000 years BP based on paired ${ }^{230} \mathrm{Th} /{ }^{234} \mathrm{U} /{ }^{238} \mathrm{U}$ and ${ }^{14} \mathrm{C}$ dates on pristine corals. Quaternary Science Reviews 24, 1781-1796.

García Cortés, Á., Gallego Valcarce, E., Barettino Fraile, D. (Eds.), 1999. Atlas de medio natural de la Región de Murcia. ITGE and Región de Murcia, Murcia.

Giménez, J., Suriñach, E., Goula, X., 2000. Quantification of vertical movements in the eastern Betics (Spain) by comparing levelling data. Tectonophysics 317, 237-238.

Gómez Espín, J.M., Gil Meseguer, E., García Marín, R., 2005. Insuficiencia hídrica y modernización de regadíos en la cuenca de Mula. Papeles de Geografía 41-42, $101-121$.

Harvey, A.M., 1984. Aggradation and dissection sequences on Spanish alluvial fans: influence on morphological development. Catena 11, 289-304.

Hughen, K., Southon, J., Lehman, S., Bertrand, C.A., Turnbull, J., 2006. Marinederived ${ }^{14} \mathrm{C}$ calibration and activity record for the past 50,000 years updated from the Cariaco Basin. Quaternary Science Reviews 25, 3216-3227.

IGME, 1972a. Mapa Geológico de España E. 1:50.000. Hoja 911-Cehegín. Instituto Geológico y Minero de España, Madrid.

IGME, 1972b. Mapa Geológico de España E. 1:50.000. Hoja 912-Mula. Instituto Geológico y Minero de España, Madrid.

Jordá Pardo, J.F., 2007. The wild river and the last Neanderthals: a palaeoflood in the geoarchaeological record of the Jarama Canyon (Central Range, Guadalajara province, Spain). Geodinamica Acta 20 (4), 209-217.

Kooistra, M.J., Pulleman, M.M., 2010. Features related to faunal activity. In: Stoops, G., Marcelino, V., Mees, F. (Eds.), Interpretation of Micromorphological Features of Soils and Regoliths. Elsevier, Amsterdam, pp. 397-418.

Macphail, R.I., Courty, M.A., Hather, J., Wattez, J., 1997. The soil micromorphological evidence of domestic occupation and stabling activities. In: Maggi, R. (Ed.) Arene Candide: a Functional and Environmental Assessment of the Holocene Sequence (Excavations Bernabò Brea-Cardini 1940-50). Memorie dell'Istituto Italiano di Paleontologia Umana, pp. 53-88.

Mallol, C.A., Hernández, C.A.M., Machado, J., 2012. The significance of stratigraphic discontinuities in Iberian Middle-to-Upper Palaeolithic transitional sites. Quaternary International 275, 4-13.

Martín-Martín, M., Martín-Algarra, A., 2002. Thrust sequence and syntectonic sedimentation in a piggy-back basin: the Oligo-Aquitanian Mula-Pliego Basin (Internal Betic Zone, SE Spain). Comptes Rendus de l'Académie de Science de Paris 334, 363-370.

Martínez, C.A., 1997. El yacimiento musteriense de Cueva Antón (Mula, Murcia). Memorias de Arqueología de la Región de Murcia 6, 18-47.

Masana, E., Pallàs, R., Perea, H., Ortuño, M., Martínez-Díaz, J.J., García-Meléndez, E., Santanach, P., 2005. Large Holocene morphogenic earthquakes along the Albox fault, Betic cordillera, Spain. Journal of Geodynamic 40, 119-133.

Mather, A.E., Silva, P.G., Goy, J.L., Harvey, A.M., Zazo, C.A., 1995. Tectonic versus climate: an example from Late Quaternary aggradational and dissectional sequences of the Mula Basin, Southeast Spain. In: Lewin, J., Mackling, M.G. Woodwards, J.C.A. (Eds.), Mediterranean Quaternary River Environment. Balkema, Rotterdam, pp. 77-87.

Moore, R.C.A., 1949. Meaning of facies. In: Longwell, C.A.R. (Ed.), 1949. Sedimentary Facies in Geological History, vol. 39. Geological Society of America Memoir, pp. $1-34$.

Ricci Lucchi, F., 1980. Sedimentologia, vol. 3. CLUEB, Bologna.

Sanchis, A., 2012. Los lagomorfos del Paleolítico medio de la vertiente mediterránea ibérica. Trabajos Varios del SIP 115. Museu de Prehistòria de València, València.

Soil Survey Staff, 1999. Soil Taxonomy. A Basic System of Soil Classification for Making and Interpreting Soil Surveys. USDA-NCRS, Washington DCA.

Stoops, G., 2003. Guidelines for Analysis and Description of Soil and Regolith Thin Sections. Soil Science Society of America, Madison.

Zilhão, J., 2006. Neandertals and moderns mixed, and it matters. Evolutionary Anthropology 15, 183-195.

Zilhão, J., Villaverde, V., 2008. The middle Paleolithic of Murcia. Treballs D’Arqueologia 14, 229-248.

Zilhão, J., Angelucci, D.E., Badal-García, E., d'Errico, F., Daniel, F., Daye, L., Douka, K. Higham, T.F.G., Martínez-Sánchez, M.J., Montes-Bernárdez, R., MurciaMascarós, S., Pérez-Sirvent, C.A., Roldán-García, C.A., Vanhaeren, M., Villaverde, V. Wood, R., Zapata, J., 2010. Symbolic use of marine shells and mineral pigments by Iberian neandertals. Proceedings of the National Academy of Science of the USA 107 (2), 1023-1028

Zilhão, J., Angelucci, D.E., Burow, C.A., Hilgers, A., Kehl, M., Villaverde, V. Wood, R., Zapata, J., 2012. From Late Mousterian to Evolved Aurignacian: New Evidence for the Middle-to-Upper Paleolithic Transition in Mediterranean Spain. Abstracts European Society for the Study of Human Evolution, Bordeaux, p. 176. 